\title{
The insulin factory: a tour of the plant surroundings and a visit to the assembly line
}

\author{
The Minkowski lecture 1973 revisited
}

\author{
L. Orci \\ Institute of Histology and Embryology, University of Geneva, Geneva, Switzerland
}

Key words: Islet of Langerhans, pancreatic B cell, (pro)insulin biosynthesis, clathrin-coated granules, acidic compartments, (pro)insulin degradation, cell polarity, immunocytochemistry.

The opportunity given to a former Minkowski awardee to review the development which has occurred in his field of research over the last 10 years makes it natural to consider, as an introduction, the summary of his 1973 lecture [1]. It reads: "We will discuss the following problems, essentially from a morphological standpoint: (a) the biosynthesis of (pro)insulin; (b) the formation of the secretory granules; (c) the release of the secretory granules; (d) the recycling of membrane constituents associated with secretion, and (e) the intercellular contacts within the islet."

Since then, I have had the opportunity of writing two updated articles, in 1982 [2] and 1984 [3] respectively, in which the five topics mentioned above were covered. In the present paper, I will therefore concentrate on very recent developments concerning the biosynthesis, maturation and degradation of insulin, and the organisation of endocrine cells within the islets of Langerhans.

\section{(Pro)insulin biosynthesis, sorting and conversion}

The initial events in the life of (pro)insulin involve biosynthesis as preproinsulin on the rough endoplasmic reticulum (RER) $[4,5]$, removal of the signal sequence at the latter level and transfer of the proinsulin molecule to the Golgi apparatus via transfer vesicles issued from transitional elements of the RER [1-3]. The Golgi apparatus has been implicated in two critical steps of the manufacturing and targeting of insulin: proteolytic maturation to the definitive hormone and sorting of (pro)insulin polypeptides from other RER-derived proteins (e.g. lysosomal enzymes) to insulin-containing secretory granules. A precise picture of how these different events are distributed at the subcellular level is now emerging from the combined use of high resolution quantitative autoradiography, immunocytochemistry and measurements of cellular and secreted proinsulin and insulin by gel chromatography and immunoassay.

Let us first consider the progress made in high resolution autoradiography. Figure 1 shows the classical electron microscope image of the intracellular compartments of the B cell involved in (pro)insulin biosynthesis, together with the graphical representation of proinsulin to insulin conversion and the distribution of intracellular radioautographic grains as published in 1973 [6]. At that time (see also [7]), autoradiographic reaction due to ${ }^{3} \mathrm{H}$-labelled secretory products was evaluated as percent of radioautographic grains distributed over RER, Golgi complex and secretory granule compartments: this mode of evaluation properly showed, over an $85-\mathrm{min}$ chase period following a 5 -min ${ }^{3} \mathrm{H}$-leucine pulse, the emptying of the radioactive products from the RER, the filling up of the Golgi peaking at 30 min post-pulse, followed by the filling up of secretory granules (peaking at $60 \mathrm{~min}$ post-pulse) upon emptying of the Golgi-associated radioactivity. By gel chromatography, proinsulin to insulin conversion became evident between 15 and 30 min post pulse. Although the basic pattern of migration of (pro)insulin-associated radioactivity from the RER to the secretory granules during a pulse-chase experiment has remained fully verified, more recent refinements in the mode of quantitative evaluation of the autoradiographic reaction have allowed the "subfractionation" of the Golgi step and the identification of an additional compartment between the Golgi and the mature insulin-containing secretory granules. When a morphometric analysis [8] coupled to the probability circle method [9] was used to assess the distribution of the au- 

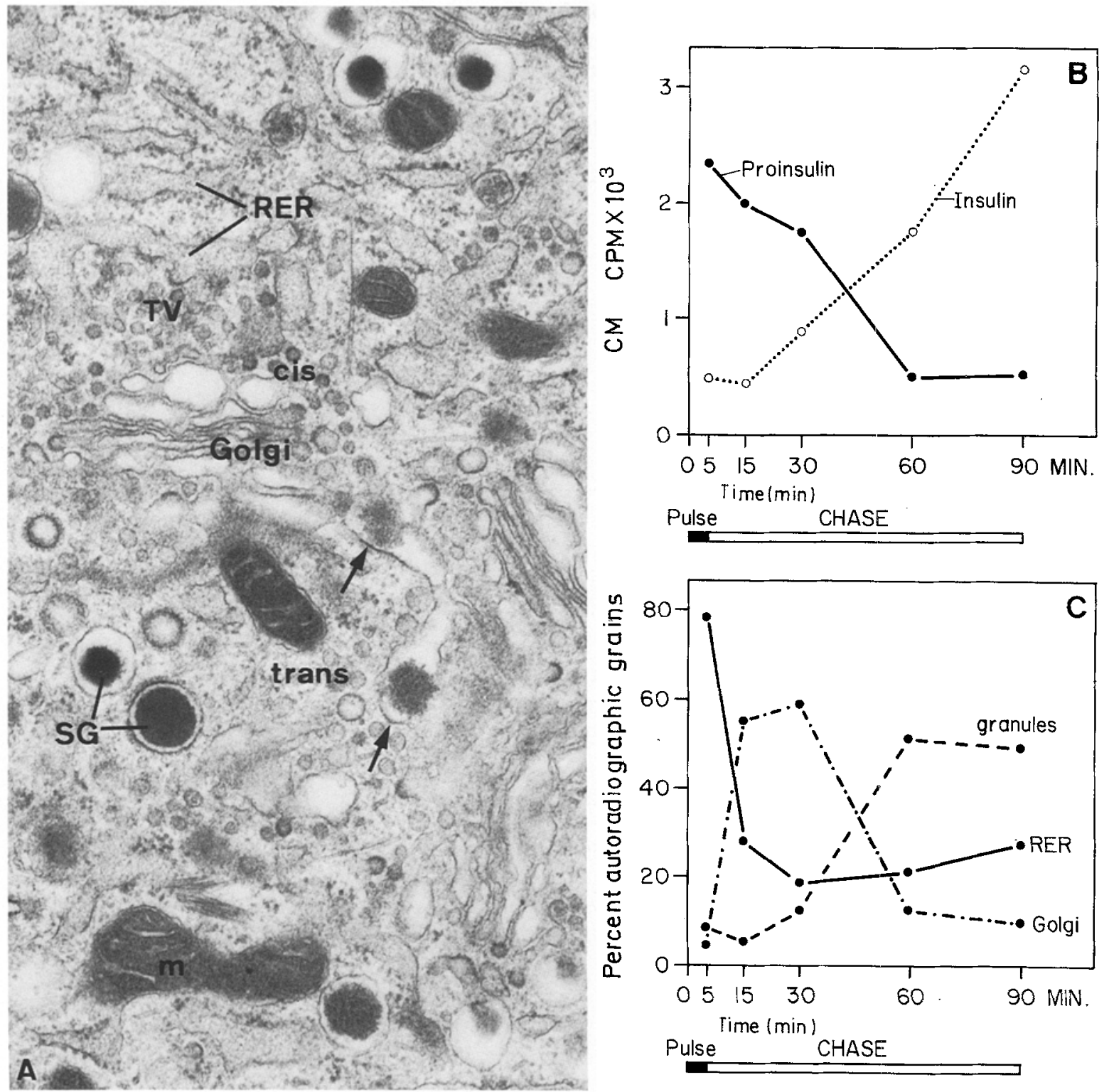

Fig. 1. A Field of a B-cell cytoplasm showing the four compartments involved in (pro)insulin processing. The rough endoplasmic reticulum (RER) is the compartment of biosynthesis of the prohormone the latter being moved to the cis pole of Golgi complex by way of transfer vesicles (TV) budding from RER cisternae. In the Golgi complex, proinsulin is funnelled within cisternae to reach the trans pole where it is concentrated in dilated extremities of trans cisternae (arrow). The pinching off of such segments of cisternae yield individual secretory granules (SG) (magnification $\times 31000$ ). For the subdivision of secretory granules in two subclasses see Figure 2 . B Radioactivity due to immunoreactive proinsulin and insulin as determined by chromatography of homogenates of islet cell monolayer cultures during a pulse-chase experiment (data derived from [6]). C Radioactivity in B-cell compartments as determined by electron microscope autoradiography during a pulse-chase experiment as in $\mathbf{B}$. Note that the time point at which proinsulin and insulin curves cross in $\mathbf{B}$ corresponds to that at which curve of radioactivity in the Golgi complex crosses with that in secretory granules (data derived from [6])

toradiographic grains in the Golgi area, a new pattern became apparent (Fig. 2). With the same pulse-chase protocol, the autoradiographic reaction on the Golgi stack was now found to peak at $15 \mathrm{~min}$ post pulse (i.e. 10 min of chase), while a new peak of autoradiographic reaction appeared between 15 and $30 \mathrm{~min}$. This corresponds to the specific labelling of a subpopulation of secretory granules in the Golgi area characterized by the presence of a coat (Fig. 2) [2,3] which contains clathrin (see below). Retrospectively, one can ascribe this difference to the previous delimitation of the Golgi area, which, in the earlier less sensitive evaluation, comprised not only the stack of cisternae but also the now separate entity represented by the coated secretory granules and condensing material within trans-coated Golgi cisternae from which coated secretory granules are released [2].

When the profile of gel chromatography showing proinsulin and insulin contents was then superimposed upon the profile of the autoradiographic reaction in the newly-defined Golgi compartments, it became evident that the bulk of conversion (i.e. the inversion of proin- 
sulin/insulin ratio) was followed at the ultrastructural level by the transfer of radioactivity into non-coated secretory granules. These data implied a critical role of the coated granules in conversion. An attempt towards the more precise demarcation of the subcellular site for proinsulin conversion was carried out using the following strategies: one consisted of perturbing the Golgi structure and function with the ionophore monensin (for a review of its effects see [10]); another was to render the proinsulin molecule resistant to proteolytic
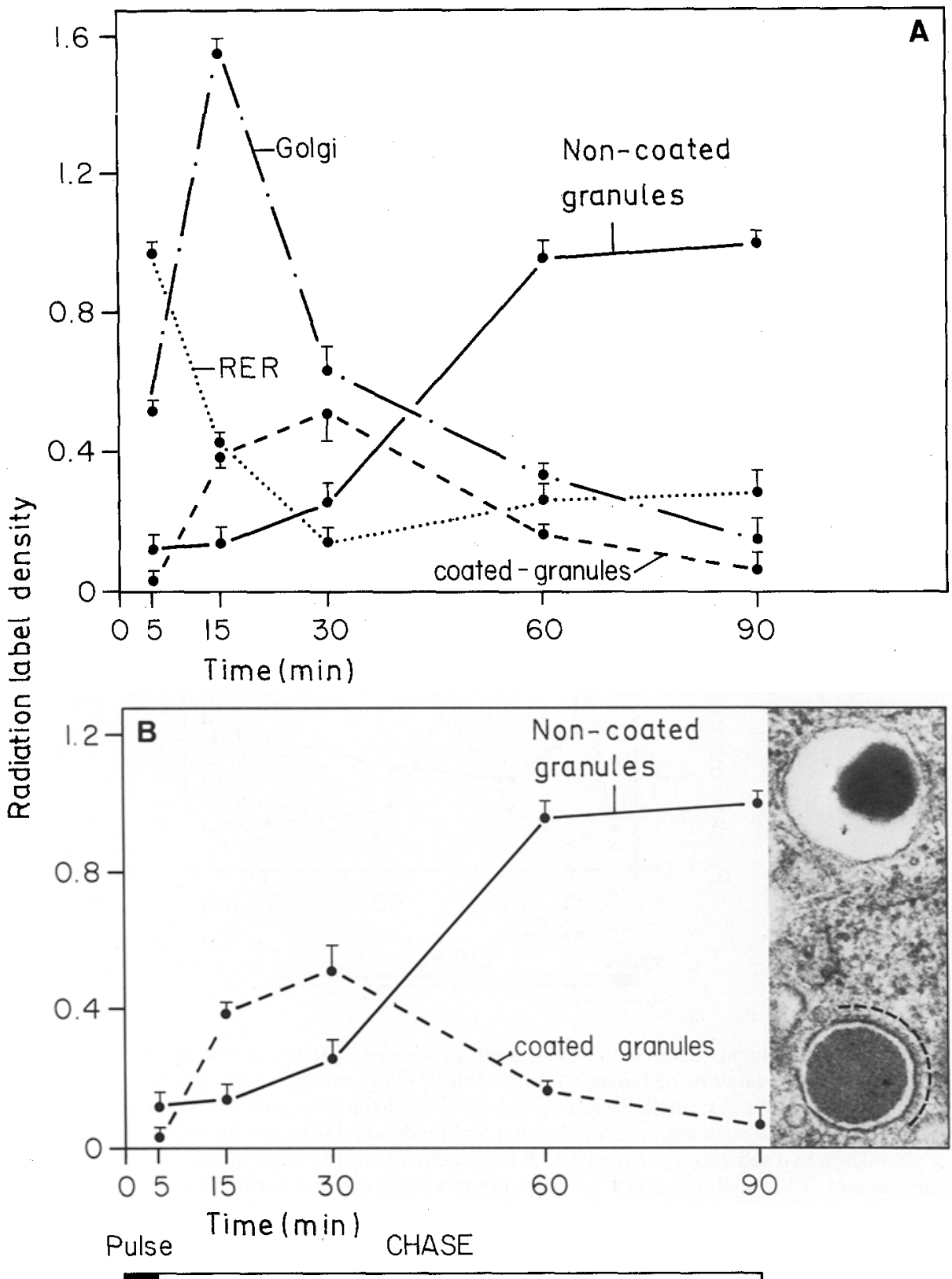

Fig. 2. A Pattern of autoradiographic labelling of B-cell compartments involved in the processing of (pro)insulin as evaluated quantitatively with the probability circle [8] coupled to morphometry [9]. (Taken from [2]). B Detail of A showing the time course of radioactivity in coated and non-coated secretory granule population during a pulse-chase experiment with ${ }^{3} \mathrm{H}$-leucine. The typical morphology of each granule type is shown in the inset. The coat on part of the coated granule membrane is indicated by a dotted line. Radiation label density represents the amount of radioactivity in the compartments considered per unit B-cell volume [8,9]. Inset: $\times 36000$

Fig.3 A-D. Thin sections ( $A$ and B) and freeze-fracture replicas (C and D) of vacuoles (CV) induced by monensin which accumulate non converted prohormone (see also Fig. 4). A Golgi region of a B cell with numerous dilated vacuoles (CV) with or without secretory granule core material. Vacuoles are numerous on the trans pole of the Golgi. The dotted line on some of them indicates a coated segment of their limiting membrane which is shown at higher magnification in the inset. B Demonstration of clathrin immunoreactive sites by the protein A-gold technique. Gold particles (arrows) decorate extensive segments of the limiting membrane of two dilated vacuoles (CV). C Freeze-fracture image of the limiting membrane of a coated vacuole (CV). On this fracture face (cytoplasmic, outer leaflet = P-face), one notes an aggregate (asterisk) of large particles (diameter: $18 \pm 3 \mathrm{~nm}$ ) which are associated with the coated region [52]. D Freeze-fracture preparation in which the tissue was treated with the cytochemical probe for cholesterol, filipin. Filipin-sterol complexes, which appear as deformations of the fracture plane (circles) larger than the protein particles are absent from extensive areas of the vacuole membrane (CV) (inner leaflet $=\mathrm{E}$-face). These areas are characteristic of coated membrane regions [53]. Quantitation showed that the coat occupies $30 \%$ of the granule perimeter.

A $\times 38000$; inset: $\times 84000 ; \mathbf{B} \times 65000 ; \mathbf{C} \times 80000 ; \mathbf{D} \times 77000$ 


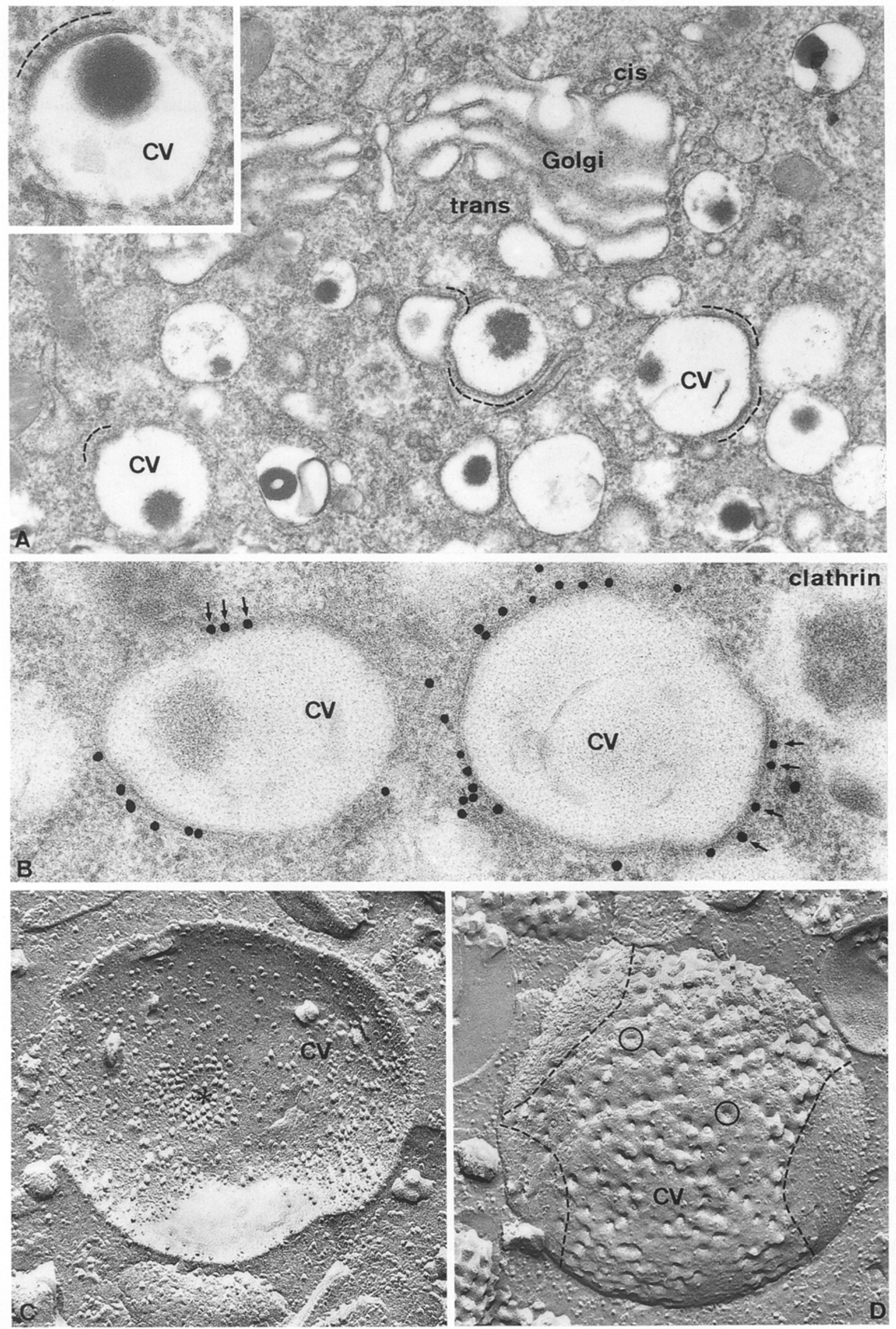



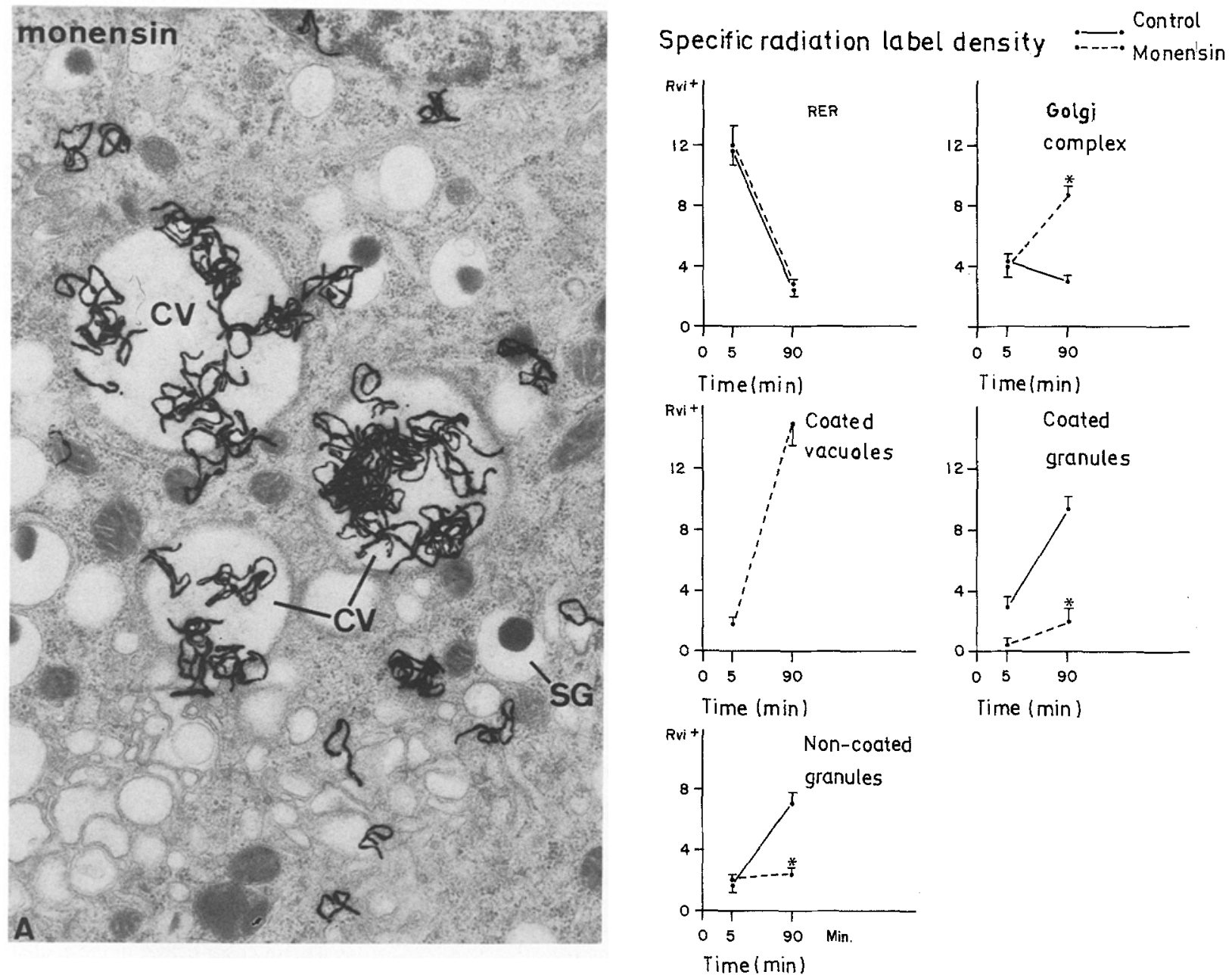

Fig.4. A Autoradiographic reaction of the Golgi region of a B cell treated with monensin and pulse-chased with ${ }^{3} \mathrm{H}-\mathrm{leucine}$. At $90 \mathrm{~min}$ of the pulse-chase experiment, most of the autoradiographic grains are situated over dilated coated vacuoles $(\mathrm{CV})$. $\mathrm{SG}=$ non-coated secretory granule. B Quantitative evaluation of the autoradiographic reaction in monensin-treated and control $\mathrm{B}$ cells during a pulse-chase experiment with ${ }^{3} \mathrm{H}$ leucine. In monensin-treated cells, note the accumulation of radioactivity in the Golgi complex and in dilated coated vacuoles at the end of the chase period. Data are means \pm SEM $n=6$ (number of islets). The asterisks indicate a significant difference $(p<0.001)$ between monensin-treated and control B cells. The specific radiation label density represents the amount of radioactivity per unit volume of the compartment considered. (For the detail of the quantitative evaluation see [12]). $\mathbf{A} \times 17000$

cleavage by substituting the amino acids arginine and lysine by their respective analogs canavanine and thialysine [11]. Arginine or lysine are the constituents of the dibasic pairs at position 31-32 and 64-65 which are removed by the converting enzyme(s). The usual pulsechase labelling of isolated islets with ${ }^{3} \mathrm{H}$-leucine was carried out, the subcellular localization of ${ }^{3} \mathrm{H}$-labelled (pro)insulin polypeptides was determined by autoradiography and their cellular and extracellular (secreted) concentrations assessed by gel chromatography.

In the presence of monensin $(50 \mathrm{nmol} / 1)$, the Golgi apparatus undergoes morphological changes consisting of a swelling of the cisternae at the trans pole including newly formed coated secretory granules (Fig.3). When the distribution of the intracellular radioactivity was assessed in these conditions, we could show that the normal pattern of transfer of radioactive products from the RER to the mature non-coated secretory granules was perturbed: radioactivity accumulated during the chase period in the dilated compartment which was characterized by a clathrin coat on part of its limiting membrane (Fig.4). This clathrin-coated compartment comprised dilated extremities of trans most Golgi cisternae with condensing secretory material and individual coated secretory granules. At the same time, the non-coated mature secretory granules showed a markedly reduced level of radioactivity as compared to controls (Fig.4). We could show that at the end of the 85 -min chase period, $65 \%$ of the immunoprecipitable radioactive products remained in the proinsulin fraction as compared to $18 \%$ in controls [12].

When amino acid analogs were used to substitute for arginine and lysine in the newly-synthetized proinsulin molecule, the morphology of the Golgi area in treated B cells was not modified, but we observed a lack of clearing of the autoradiographic reaction from coated granules during the 85 -min chase period (Fig.5). Non-coated granules remained weakly labelled. Bio- 

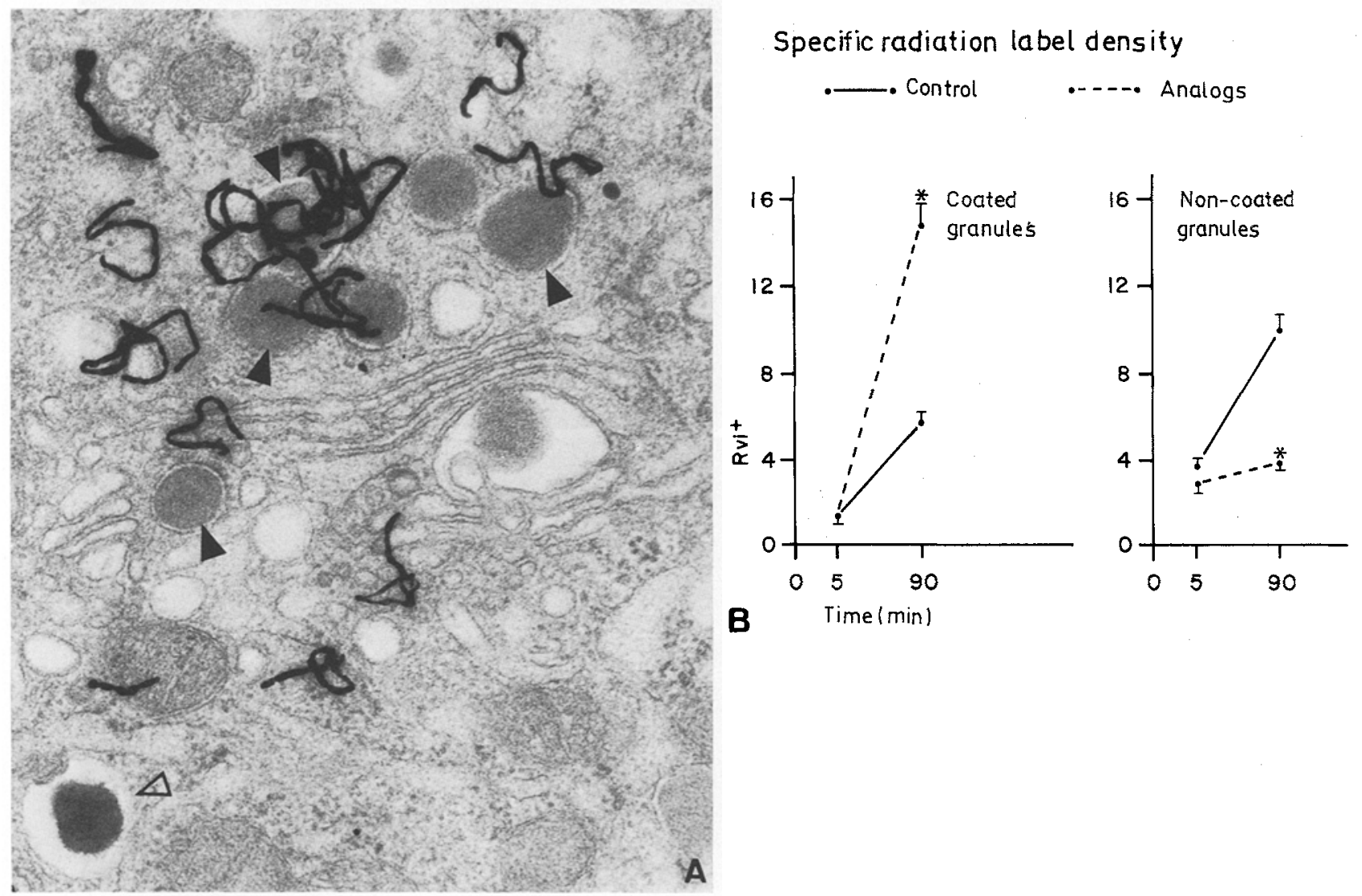

Fig.5 A Autoradiographic reaction of the Golgi region of a B cell treated with aminoacid analogs and pulse-chased with ${ }^{3} \mathrm{H}$-leucine. At 90 min of the pulse-chase experiment, most of the autoradiographic grains are situated over coated secretory granules (black arrowheads). The non-coated granule visible on this field (white arrowhead) is not labelled. B Quantitative evaluation of the autoradiographic reaction in analog-treated B cells during a pulse-chase experiment with ${ }^{3} \mathrm{H}$-leucine. Note the accumulation of radioactivity during the 85-min chase period in the coated granules. At the same time point in controls, non-coated granules are labelled. Data are means \pm SEM $n=6$ (number of islets). The asterisks indicate a significant difference $(p<0.05)$ between control and analog-treated cells at the 90 -min time point. The specific radiation label density represents the radioactivity per unit volume of the compartment considered. (For detail of the quantitative evaluation see [13]). $\mathbf{A} \times 34000$

chemical analysis showed that, at that time, $89 \%$ of radiolabelled immunoprecipitable products were in the form of proinsulin in analog-treated islets, as compared to $22 \%$ in controls [13]. Using two different experimental protocols, one that interferes with the intracellular transfer (and release) of (pro)insulin polypeptides (monensin), and the other one rendering the proinsulin molecule insensitive to proper proteolytic cleavage (analogs), we made the same observation, i. e. that proinsulin conversion was impaired and that radioactive secretory products accumulated in a clathrin-coated, Golgi-related compartment of the B cell.

This can be taken as compelling evidence that conversion of proinsulin is linked to its unperturbed passage through a clathrin-coated Golgi-related compartment and to the subsequent maturation of the latter into non-coated storage secretory granules. If this interpretation is correct, the coated compartment of the B cell (excluding of course that related to receptor-mediated endocytosis at the cell surface) would represent the proinsulin-rich compartment in which the bulk of conversion takes place. Uncoating of the coated secretory granules to yield non-coated mature granules might then be linked to the attainment of a critical internal milieu (e.g. proinsulin content, $\mathrm{pH}$, see below) inside the converting compartment. Since monensin blocks the intracellular migration of polypeptides, one could argue that the accumulation of non-converted secretory product in the coated compartment does not necessarily imply that this is the converting compartment; the results could as well suggest that monensin prevents the entry of proinsulin from the coated Golgi-derived compartment to a subsequent compartment where conversion would effectively take place. Not until very recently could this issue be directly approached, when a novel immunocytochemical tool allowing the specific localisation of proinsulin became available: a series of monoclonal antibodies (Mabs) was raised against recombinant proinsulin, with one group showing unique specificity towards an epitope spanning the dibasic processing site at the B-C junction [14]. We found this epitope (present in human and rat proinsulin, but neither in insulin nor in C-peptide) to be preserved in aldehyde-fixed, plasticembedded tissues, thus allowing the specific localization of the prohormone on thick (Fig. 6) and thin sections (Fig. 7). With this tool (GS-9A8 Mab), we could es- 

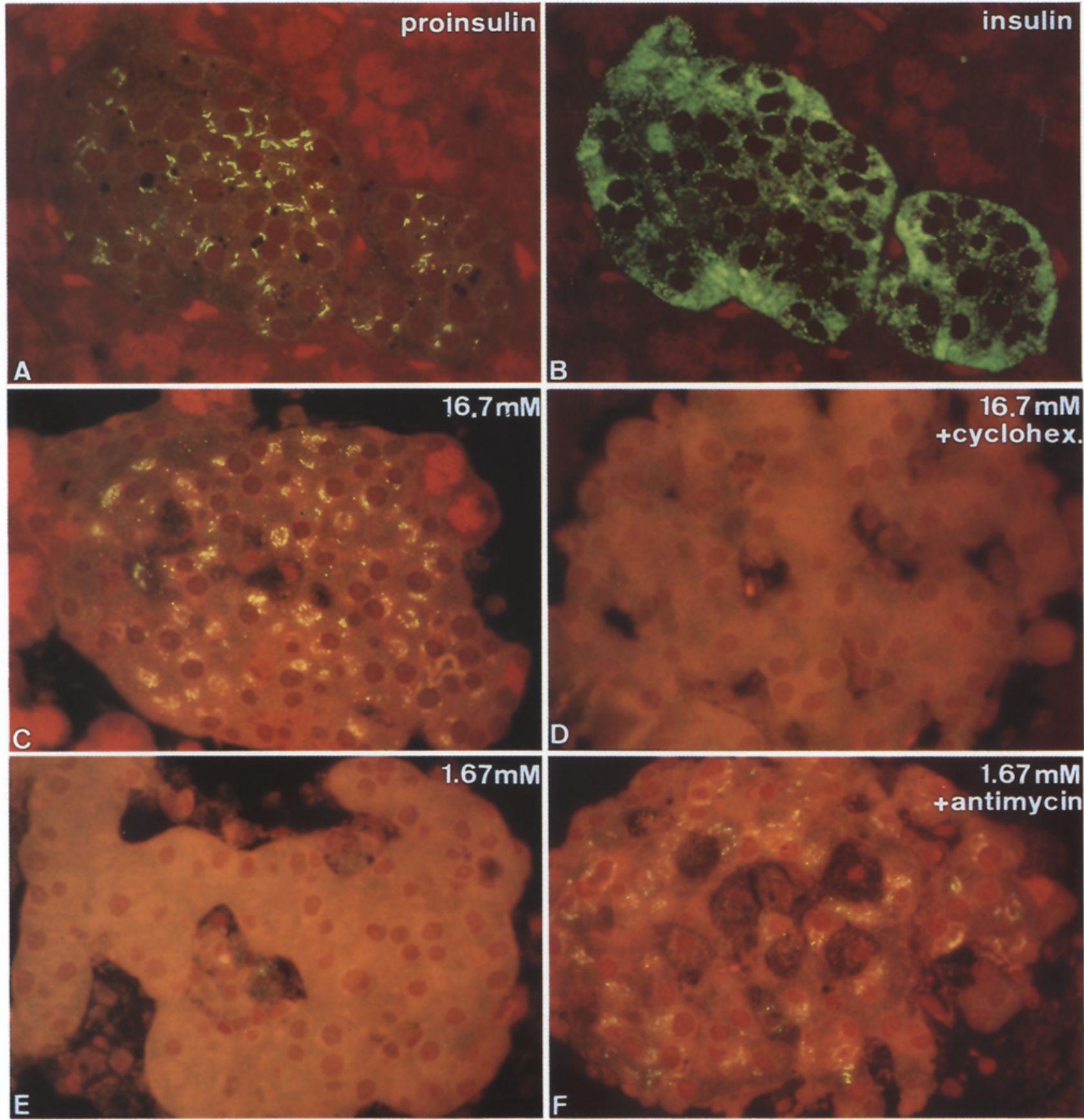

Fig. 6. A-B Consecutive serial sections of a human islet stained by immunofluorescence with anti-proinsulin GS-9A8 monoclonal antibody (A) and polyclonal anti-insulin serum (B). Proinsulin immunofluorescence takes the form of perinuclear crescent-shaped ribbons. Anti-insulin serum elicits a diffuse, punctate cytoplasmic staining. C-F Rat isolated islets incubated under various experimental conditions which modulate proinsulin content of B cells. C shows a strong intensity of proinsulin immunofluorescence following a 60 -min incubation of the islet in $16.7 \mathrm{mmol} / 1$ glucose; E shows the disappearance of proinsulin immunofluorescence in islets first exposed ( $60 \mathrm{~min}$ ) to a $16.7 \mathrm{mmol} / 1 \mathrm{glucose} \mathrm{concentration}$ then transferred (for $60 \mathrm{~min}$ ) to a medium containing $1.67 \mathrm{mmol} / 1$ glucose; $\mathrm{D}$ illustrates the lack of proinsulin immunofluorescence in B cells of islets preincubated in $16.7 \mathrm{mmol} / 1$ glucose then exposed to cycloheximide $(5 \mu \mathrm{g} / \mathrm{ml})(60 \mathrm{~min})$ to block protein synthesis in the continuous presence of a $16.7 \mathrm{mmol} / 1$ glucose; $\mathbf{F}$ shows the persistence of proinsulin immunoreactivity in B cells first exposed to $16.7 \mathrm{mmol} / 1 \mathrm{glucose}(60 \mathrm{~min})$, then transferred to a medium containing $1.67 \mathrm{mmol} / 1$ glucose in presence of $10 \mu \mathrm{mol} / 1$ antimycin A. See Table 2 for quantitation of proinsulin immunoreactive sites at the ultrastructural level in these various conditions. Glutaraldehyde fixation; Epon embedding.

A-F $\times 540$

Fig. 7 A-C. Thin sections of B cells immunostained with proinsulin monoclonal antibody (A) or anti-clathrin polyclonal antibody (B, C). Proinsulin immunoreactive sites revealed by gold particles (arrows) are concentrated over the membranes of the Golgi complex and two associated secretory granules (black arrowheads). Such granules show clathrin immunolabelling (see C). Secretory granules with a peripheral halo (white arrowheads) and which lack clathrin immunostaining (see B) are weakly labelled by the proinsulin antibody; B shows that clathrin immunoreactive sites (arrows) predominate on the trans pole of the Golgi complex. The arrowhead indicates a forming granule in a clathrin labelled trans cisterna. Cillustrates clathrin-rich compartments (arrows) in a Golgi region comprising two coated secretory granules (arrowheads) and a trans Golgi cisternae (G). See Table 1 for the content of proinsulin immunoreactive sites over various B-cell compartments and Table 3 for the quantitative evaluation of clathrin immunolabelling in the Golgi area. Protein A-gold technique [54]. Lowicryl $\mathrm{K}_{4} \mathbf{M}$ low temperature embedding [55]. $\mathbf{A} \times 52000 ; \mathbf{B} \times 37000 ; \mathbf{C} \times 52000$ 

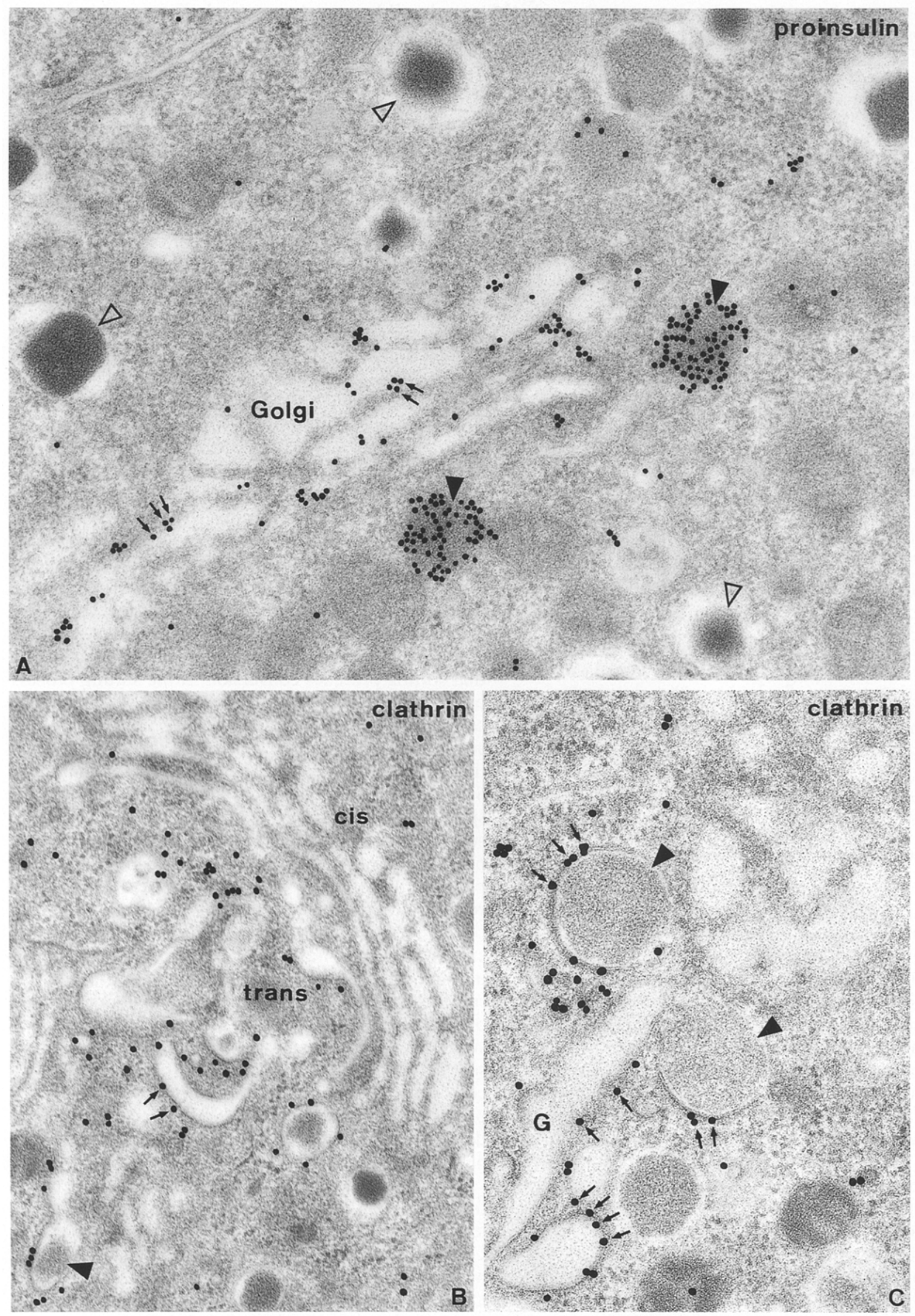
Table 1. Density of proinsulin immunolabelling (GS-9A8 Mab) on B-cell compartments of rat pancreatic islets "in situ"

\begin{tabular}{lc}
\hline & Number of gold particles $/ \mu \mathrm{m}^{2}$ \\
\hline Rough endoplasmic reticulum & $5 \pm 1(1045)$ \\
Golgi stack & $41 \pm 4(3542)$ \\
Coated granules & $726 \pm 77(7371)$ \\
Non-coated granules & $11 \pm 1(722)$ \\
\hline
\end{tabular}

Result expressed as mean $\pm S E M ; n=7$ (number of islets). The numbers in parentheses indicate the total count of gold particles evaluated.

The human proinsulin specific monoclonal antibody (GS-9A8 Mab) used has been previously characterized [14]. The epitope recognized by GS-9A8 Mab is located around the dibasic processing site (Arg-Arg) at position 31-32 in human proinsulin. Sequence comparisons around this region combined with the lack of reactivity towards porcine proinsulin in radioimmunoassay [56] and in immunocytochemistry (data not shown) strongly suggest that the aminoacid in pos. 30 (representing the only difference between human and porcine proinsulin in the region from the $\mathrm{N}$-terminus to pos.35) is critical for correct epitope structure. Apparently the loss of one methyl group in this position going from Thr (man) to Ser (rat) still allows antibody binding, whereas the additional loss of the hydroxyl group (Ala in pig) significantly alters the epitope structure

Table 2. Proinsulin immunoreactivity (GS-9A8 Mab) over B-cell compartments of isolated islets

\begin{tabular}{lccc}
\hline $\begin{array}{l}\text { Experimental } \\
\text { condition }\end{array}$ & \multicolumn{3}{c}{ Number of gold particles $/ \mu \mathrm{m}^{2}$} \\
\cline { 2 - 4 } & Golgi stack & $\begin{array}{l}\text { Coated } \\
\text { granules }\end{array}$ & $\begin{array}{l}\text { Non-coated } \\
\text { granules }\end{array}$ \\
\hline $16.7 \mathrm{mmol} / 1$ glucose & $24 \pm 2$ & $1068 \pm 83$ & $9 \pm 1$ \\
$1.67 \mathrm{mmol} / 1$ glucose & $7 \pm 2$ & $406 \pm 2$ & $8 \pm 1$ \\
$\begin{array}{l}16.7 \mathrm{mmol} / 1 \text { glucose } \\
+ \text { cycloheximide } 5 \mu \mathrm{g} / \mathrm{ml}\end{array}$ & $4 \pm 1$ & $214 \pm 45$ & $9 \pm 1$ \\
$\begin{array}{l}1.67 \mathrm{mmol} / 1 \text { glucose } \\
+ \text { antimycin A } 10 \mu \mathrm{mol} / 1\end{array}$ & $35 \pm 4$ & $315 \pm 52$ & $13 \pm 4$ \\
\hline
\end{tabular}

For all conditions indicated, isolated rat islets were preincubated for $60 \mathrm{~min}$ in a medium containing $16.7 \mathrm{mmol} / 1$ glucose, then transferred for a further $60 \mathrm{~min}$ in the various incubation media as described. Results expressed as mean $\pm \mathrm{SEM} ; n=3$ (number of islets)

tablish that two compartments of the B cell were rich in proinsulin immunoreactive sites: clathrin-coated secretory granules and Golgi stacks (Table 1). We then quantitated the immunoreaction and the size of these compartments (as volume density) under different experimental conditions in order to determine the kinetics of intracellular proinsulin transit and conversion. In conditions of stimulated protein synthesis (high glucose medium), the concentration of proinsulin immunoreactivity, as well as the volume density of coated granules were high; in conditions of reduced protein synthesis (low glucose medium or cycloheximide treatment) the number of immunoreactive sites in Golgi stacks and coated granules was low as was the volume density of coated granules (Table 2). A kinetic analysis of this modulation after transfer of islets form high to low glucose showed that the loss of immunoreactivity (due to prohormone conversion) occurred in clathrin-coated granules. When oxydative metabolism was blocked by antimycin $\mathrm{A}$ in islets preincubated in high glucose, the immunoreactivity in the Golgi stacks was not reduced by further incubation in low glucose, while both immunoreactivity and volume density of preexisting coated granules markedly decreased (Fig. 8 and Table 2). Under all conditions of incubation, non-coated granules showed a low constant level of immunoreactivity. These findings provide direct evidence that coated secretory granules represent the major if not the only cellular site of proinsulin to insulin conversion. They also suggest that the Golgi stack is not involved in conversion and that inter-cisternal transport and coated granule formation represent a hitherto unrecognized energyrequiring step that precedes conversion (Orci L, Ravazzola M, Amherdt M, Madsen OD, Vassalli JD and Perrelet A: Cell, September 1985).

Besides showing the link between the non-conversion of proinsulin and the residency of these non-converted peptides within a coated granule compartment, the use of arginine and lysine analogs also gave clues with respect to the sorting process that allows (pro)insulin to be separated from other RER-derived proteins (e.g. lysosomal enzymes) and to be channelled into $\beta$ secretory granules. Indeed, during analog treatment, coated secretory granules containing modified, unconvertible proinsulin did form as in control B cells [13], indicating that sorting of proinsulin to secretory granules could occur in absence of conversion or, in other words, that sorting precedes conversion. If the sorting process occurs before conversion, i.e. proximally to the coated compartment, it is expected to take place in the Golgi stack. For lysosomal enzymes, the proper sorting of these proteins depends on the presence of mannose6-phosphate residues which are recognized by corresponding receptors on the sorting compartment [15]; such receptors for mannose-6-phosphate have recently been demonstrated on the cisternae of the Golgi complex and this has been taken to imply that sorting of lysosomal enzymes can occur at this level $[16,17]$.

Direct evidence for a proinsulin-specific receptor is currently lacking; however, the presence of (pro)insulin immunoreactive sites (detected with an anti-insulin serum cross-reacting with proinsulin) on Golgi membranes, but not on secretory granule membranes [18], suggests that receptors or specific binding sites are present at the former level (see Fig. 7). The notion of a "receptor-mediated" intracellular sorting mechanism for proinsulin, at least at the Golgi level, is compatible with data gained by the immunocytochemical demonstration of clathrin in B cells.

Receptor-mediated endocytosis is characterized by the association of a clathrin coat with the cytoplasmic leaflet of the plasma membrane (for review see [19]). Clathrin is believed to be involved in the internalisation of membrane segments with clustered receptors [20]. Using an affinity-purified anti-clathrin antibody [21], we studied the distribution of clathrin immunoreactive 

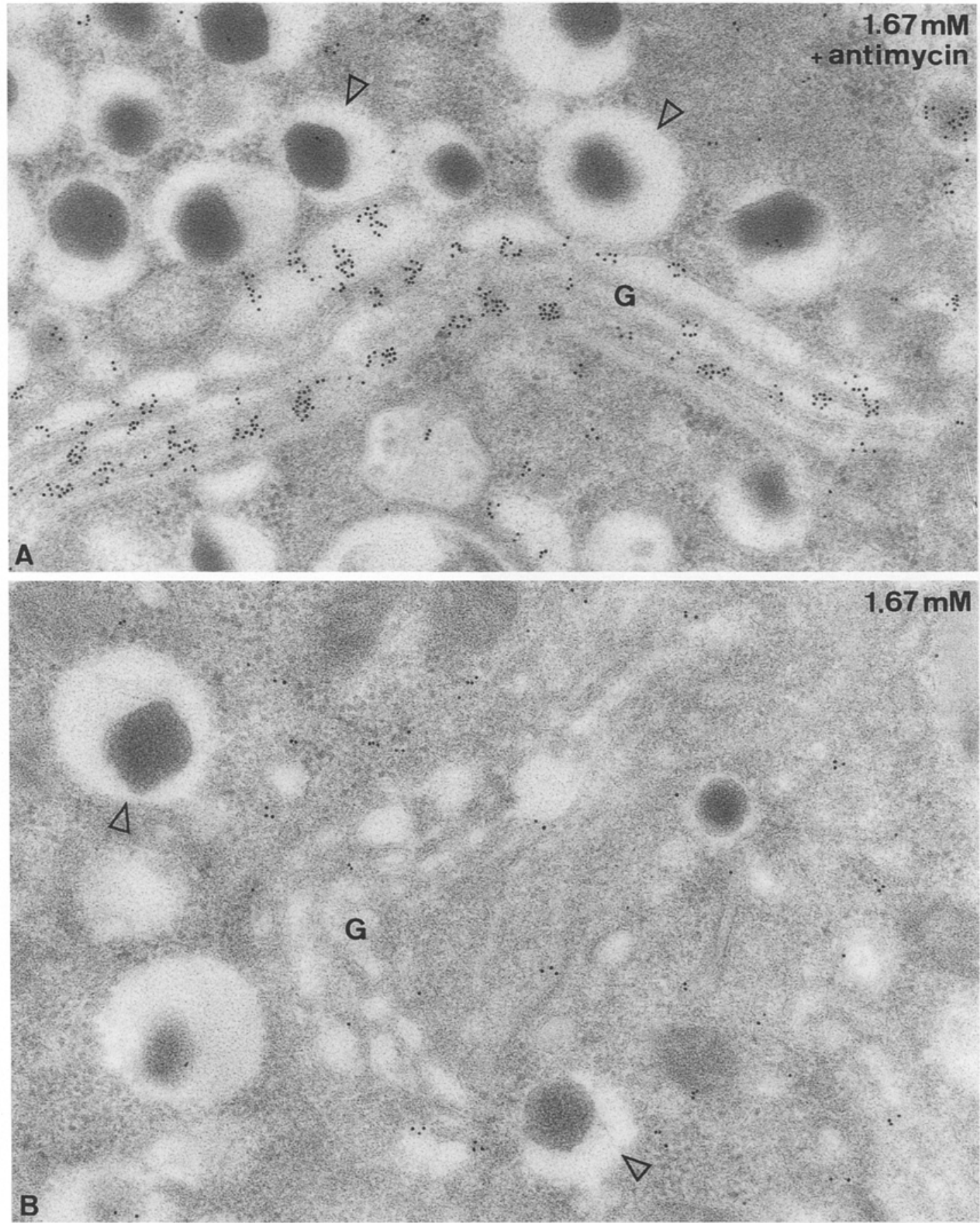

Fig. 8. A, B Thin sections of the Golgi area of B cells immunostained with proinsulin monoclonal antibody. A Isolated islets were exposed first to a high $(16.7 \mathrm{mmol} / \mathrm{l})$ glucose concentration for $60 \mathrm{~min}$, then transferred to a low glucose $(1.67 \mathrm{mmol} / \mathrm{l})$ concentration in presence of $10 \mu \mathrm{mol} / 1$ antimycin A for a further $60 \mathrm{~min}$. In this condition, the marked proinsulin labelling of the Golgi stack (G) which results from the high glucose incubation is not cleared during the second incubation in low glucose. B Incubation protocol as in A but in absence of antimycin. In this condition, the proinsulin immunoreactivity of the Golgi complex is reduced to a very low level. Non-coated secretory granules (white arrowheads) present very little proinsulin immunoreactive sites in both conditions. See Table 1 for the quantitative evaluation of the density of immunolabelling on various B-cell compartments and Table 2 for the quantitation of the antimycin experiment. Protein A-gold technique, Lowicryl $\mathrm{K}_{4} \mathrm{M}$ low temperature embedding. $\mathbf{A} \times 49000 ; \mathbf{B} \times 49000$

sites at the level of the Golgi apparatus and found a marked asymmetry of the labelling [22]: most clathrin antigenic sites were observed on trans pole of the Golgi (Table 3). If, therefore, as for the plasma membrane step, one takes typical clathrin coats as the morphologi- cal marker of what we propose to call "receptor-mediated, non-plasmalemmal intracellular transport", the trans Golgi transport which involves the detachment of coated secretory granules from coated cisternae would qualify for this definition; this would support the work- 

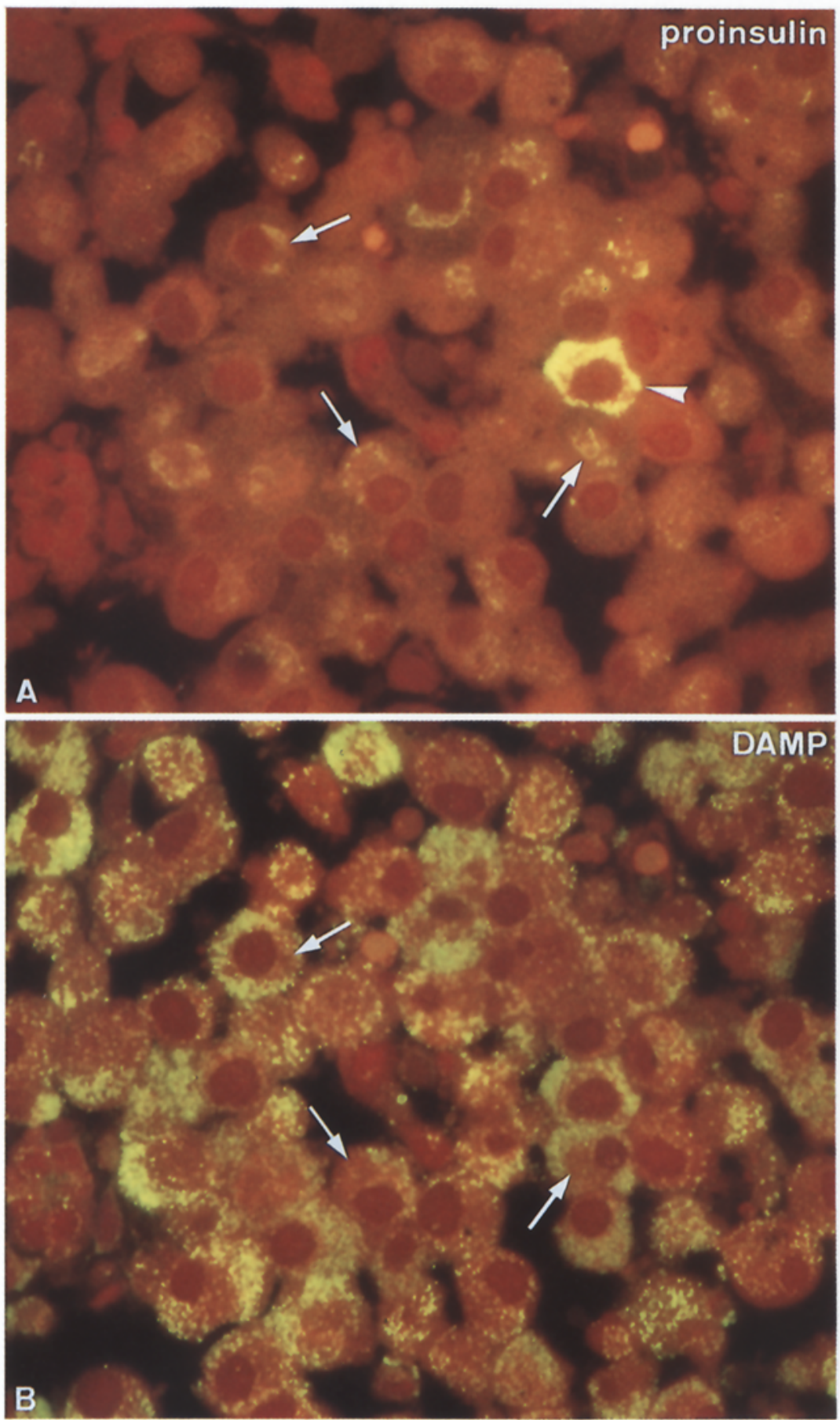

Fig.9A and B. Successive serial thick sections stained with anti-proinsulin (A) or anti-dinitrophenol (B) monoclonal antibodies. Proinsulin immunofluorescence takes the form of perinuclear crescentshaped bands indicating Golgi labelling (cf. Fig. 6). DAMP staining elicits a spotty cytoplasmic fluorescence with a weak labelling of the areas which are proinsulin-rich. The inverse labelling of proinsulin and DAMP-rich areas is indicated by arrows. An exception to this pattern is shown by the arrowhead in Figure A. This represents a cell type occasionally encountered in all experimental conditions studied and which is characterized by a strong granular fluorescence throughout the cytoplasm. Such cells can be found also in low glucose or cycloheximide-treated islets, conditions which in all other cells lead to a disappearance of proinsulin immunofluorescence (cf. Fig. 6 and Table 2); however, immunofluorescence in these cells can, as in all other B cells, be abolished by the incubation of the section in $0.06 \%$ Trypsin. Whether the atypical proinsulin immunoreactivity is due to a defect in the substrate (proinsulin), converting enzyme(s) and/or the milieu (i.e. acidity) of the conversion compartment, is presently under investigation. See legend of Fig. 10 for the conditions of DAMP labelling.

$A$ and $B \times 970$ ing hypothesis of a proinsulin receptor mechanism involved in the sorting and accumulation of this polypeptide to secretory granules.

Clathrin-coated vesicles have been shown to undergo acidification in vitro $[23,24]$ and isolated Golgi membranes contain an electrogenic $\mathrm{H}^{+}$pump [25]. It is thus also of interest to consider the relationship between the presence of clathrin on the limiting membranes of the Golgi-derived coated compartment where conversion of proinsulin takes place and the putative role of a proinsulin-converting thiol-protease with acidic $\mathrm{pH}$ optimum [26]. The intragranular $\mathrm{pH}$ was estimated to be between 5 and 6 [27]. Recently, Anderson et al. [28, 29] demonstrated that low intracellular $\mathrm{pH}$ compartments can be visualized using a basic congener of dinitrophenol, 3-(2,4-dinitroanilino)-3'amino-N-methyldipropylamine (DAMP) which accumulates in acidic vesicles and can be detected by immunocytochemistry at the light and electron microscope level with a monoclonal anti-dinitrophenol antibody (Figs.9 and 10). Our preliminary results using this probe, indicate that DAMP accumulates in large amounts within non-coated mature secretory granules (insulin-rich), but with much lower density in newly-formed coated granules (proin- 

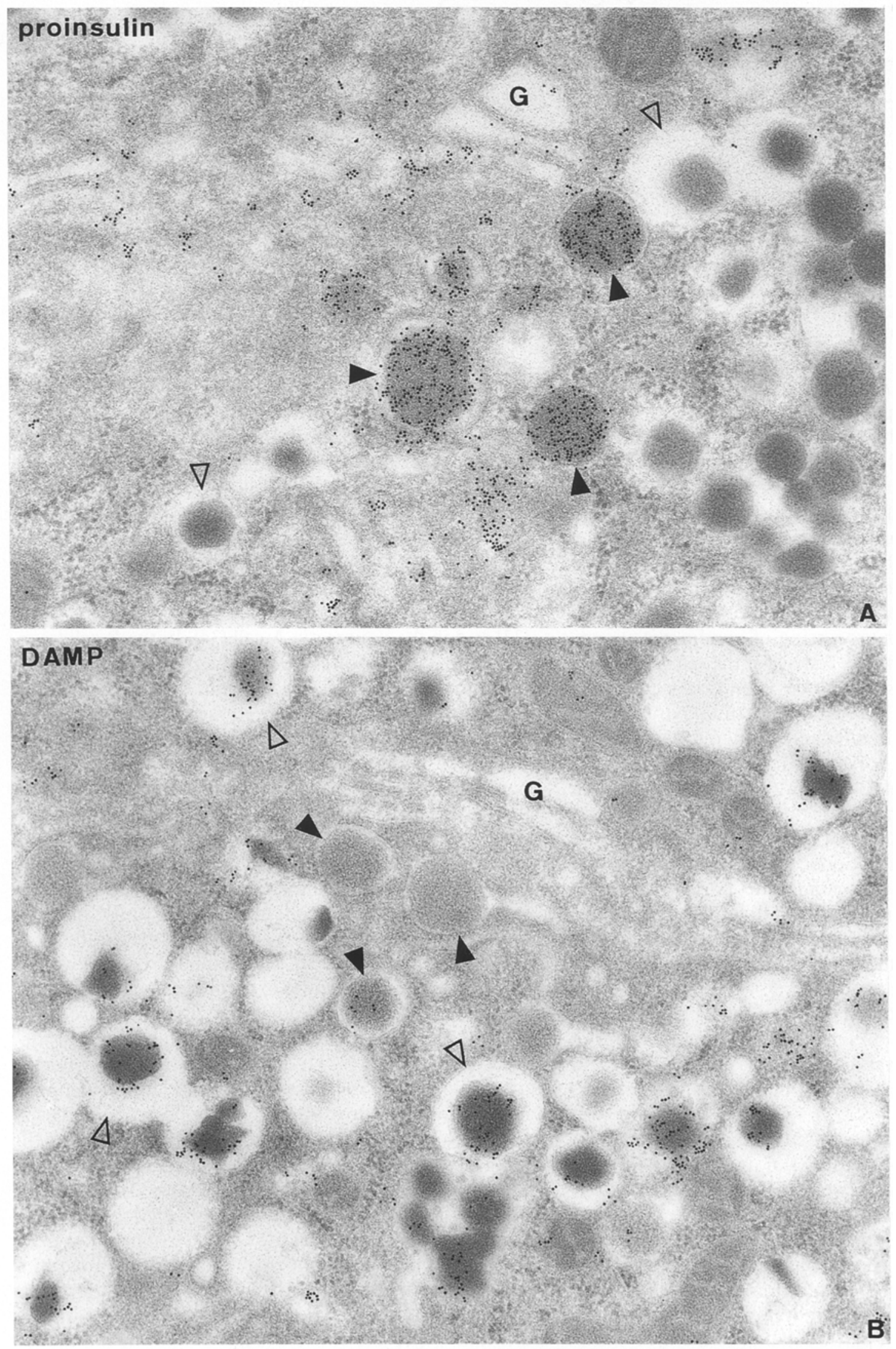

Fig. 10. A Proinsulin immunolabelling of the Golgi region of a B cell. Proinsulin antigenic sites revealed by gold particles are present on Golgi cisternae (G) and a population of secretory granules with a tightly fitting core (black arrowheads). The latter correspond to clathrin-coated granules (see Fig.7). The non-coated granules (white arrowheads) are very weakly labelled. B Immunoreactive labelling (protein A-gold technique) of DAMP (a probe which accumulates in acidic intracellular compartments [28, 29]. A marked DAMP labelling (preliminary quantitation gave $\sim 500$ gold particles $/ \mu \mathrm{m}^{2}$ ) occurs in non-coated granules (white arrowheads) which are poor in proinsulin; proinsulin-rich coated granules (black arrowheads) have a much reduced level of DAMP immunoreactivity ( $\sim 80$ particles $\left./ \mu \mathrm{m}^{2}\right)$. Nuclear labelling: $\sim 10 \mathrm{particles} / \mu \mathrm{m}^{2}$. Isolated islets were incubated for $120 \mathrm{~min}$ in $16.7 \mathrm{mmol} / 1$ glucose in absence of $\mathrm{Ca}^{++}$, then transferred for $30 \mathrm{~min}$ in the same medium containing DAMP $(50 \mathrm{mmol} / \mathrm{l})$. Immunostaining of thin sections of DAMP-treated islets was carried out as follows: a) monoclonal anti-dinitrophenol antibody $(1: 20000)$; b) rabbit antimouse IgG; c) protein A-gold. Lowicryl $\mathrm{K}_{4} \mathrm{M}$ low temperature embedding. $\mathbf{A} \times 43000 ; \mathbf{B} \times 43000$ 
Table 3. Density of clathrin immunolabelling over B-cell compartments

\begin{tabular}{lc}
\hline & Number of gold particles $/ \mu \mathrm{m}^{2}$ \\
\hline cis-Golgi & $3.46 \pm 0.41$ \\
trans-Golgi & $26.52 \pm 1.10$ \\
Subplasmalemmal rim & $3.34 \pm 0.32$ \\
Nucleus & $0.40 \pm 0.11$ \\
\hline
\end{tabular}

Results expressed as mean $\pm \mathrm{SEM}, n=11$ (number of islets). $p$ values were determined with the Student's t-test. cis-Golgi versus trans-Golgi: $p<0.001$; cis-Golgi versus subplasmalemmal rim: not significant. Affinity-purified clathrin antibody [21]. (For details of the immunolabelling procedure and quantitative evaluation see [22])

sulin-rich) (Fig. 10). Although it remains to be determined whether the partitioning properties of DAMP between different subcellular compartments are exclusively a function of local $\mathrm{pH}$, the current working hypothesis suggests that the $\mathrm{pH}$ of the converting, coated compartment is significantly higher than that of mature granules (Orci, Ravazzola, Amherdt, Vassalli, Perrelet and Anderson, unpublished data). These very new and exciting developments allow the speculation that regulation of intragranular $\mathrm{pH}$ may be critical in providing an optimal milieu for processing of insulin precursors, and/or for terminating the activity of the relevant proteolytic enzyme(s). It is easy to envision how physiological or pathological differences in the timing or extent of such $\mathrm{pH}$ changes could affect the intragranular postsynthetic modifications of proteins, including prohormones and zymogens. Based on recent data showing a relationship between intramembrane particle cluster coated membrane domains and water permeability in the kidney [30], an additional intriguing possibility to consider is that the intramembrane particle clusters/ coated membrane domains found in immature granules may be related to an increased water permeability of these regions of the granule membrane during the maturation and condensing process.

The data reviewed above have shown progresses towards a finer degree of subcellular exploration, and a commensurate integration between morphology and function for understanding the biosynthesis of (pro)insulin.

Areas in which further progress is desirable can be summarized in the following set of questions:

a) Is the intra Golgi transport, i.e. the movement of proinsulin polypeptides from the cis to the trans poles mediated by a vesicular traffic?

b) What is the signal for uncoating of coated secretory granules during their maturation into non - coated granules? Is a specific membrane organisation (such as clustered protein particles) and/or a critical intragranular milieu involved?

c) At which step of transport/sorting of proinsulin is the converting enzyme added? is the enzyme in active or inactive form at the time of addition?

d) What governs the onset and cessation of activity of the converting enzyme(s)? e) Is the enzyme(s) reused in several cycles of conversion?

The answering of each of these questions will represent critical advances towards a more complete picture of B cell function.

\section{(Pro)insulin degradation}

After having reviewed the "anabolic" side of (pro)insulin metabolism, we shall now turn towards its "catabolic" side, i. e. insulin degradation, and review some recent progress in this area.

As mentioned above, the B cell stores its final biosynthetic product in cytoplasmic granules, where it is available for secretion through exocytosis [1-3]. However, the total amount of the insulin manufactured is not destined to be secreted, since a substantial fraction can be degraded within the $B$ cell itself $[31,32]$. The assumed mechanism of insulin degradation is fusion of secretory granules with primary lysosomes, a process called granulolysis or crinophagy and initially described in the endocrine cells of the anterior pituitary [33] and in the pancreatic A cell [34]. In the B cell, morphological evidence for crinophagy consists of cytoplasmic organelles of variable morphology containing dense masses resembling $\beta$-secretory granule cores. The lysosomal nature of these structures (also called crinophagic or multigranular bodies) is evidenced by their content in lysosomal enzymes such as acid phosphatase, arylsulfatase [35] or cathepsin B (Fig. 11 C). Whether or not the granule core-like material of multigranular bodies is related to insulin polypeptides has recently been explored by immunocytochemistry at the ultrastructural level using anti-insulin and anti-C-peptide antisera [35]. A timetable of the postulated transfer of secretory granule cores into lysosomal structures was also assessed by pulse-chase experiments with ${ }^{3} \mathrm{H}$-leucine on isolated islets. The radioactivity in the mature (noncoated) secretory granule compartment slowly decreased from $3 \mathrm{~h}$ to $24 \mathrm{~h}$ after a $30-\mathrm{min}$ pulse, whereas the radioactivity in the multigranular body compartment, which was low up to $3 \mathrm{~h}$, significantly increased from 3 to $24 \mathrm{~h}$. This pattern of autoradiographic labelling, together with the morphological similarity between the cores of secretory granules and those visible in crinophagic bodies, as noted above, suggested a process of funnelling of a fraction of the radioactive peptides from the secretory granule compartment into the multigranular body compartment. All mature secretory granules were labelled by immunostaining with both anti-insulin and anti-C-peptide antisera (Fig.11 A), while multigranular bodies were labelled with the anti-insulin serum but virtually unlabelled with the anti-C-peptide serum (Fig. 11 B). Lysosomal-like structures without apparent secretory granule cores, which are assumed to represent the final stage of lysosomal digestion (hence they are called residual bodies) were devoid of both insulin and 


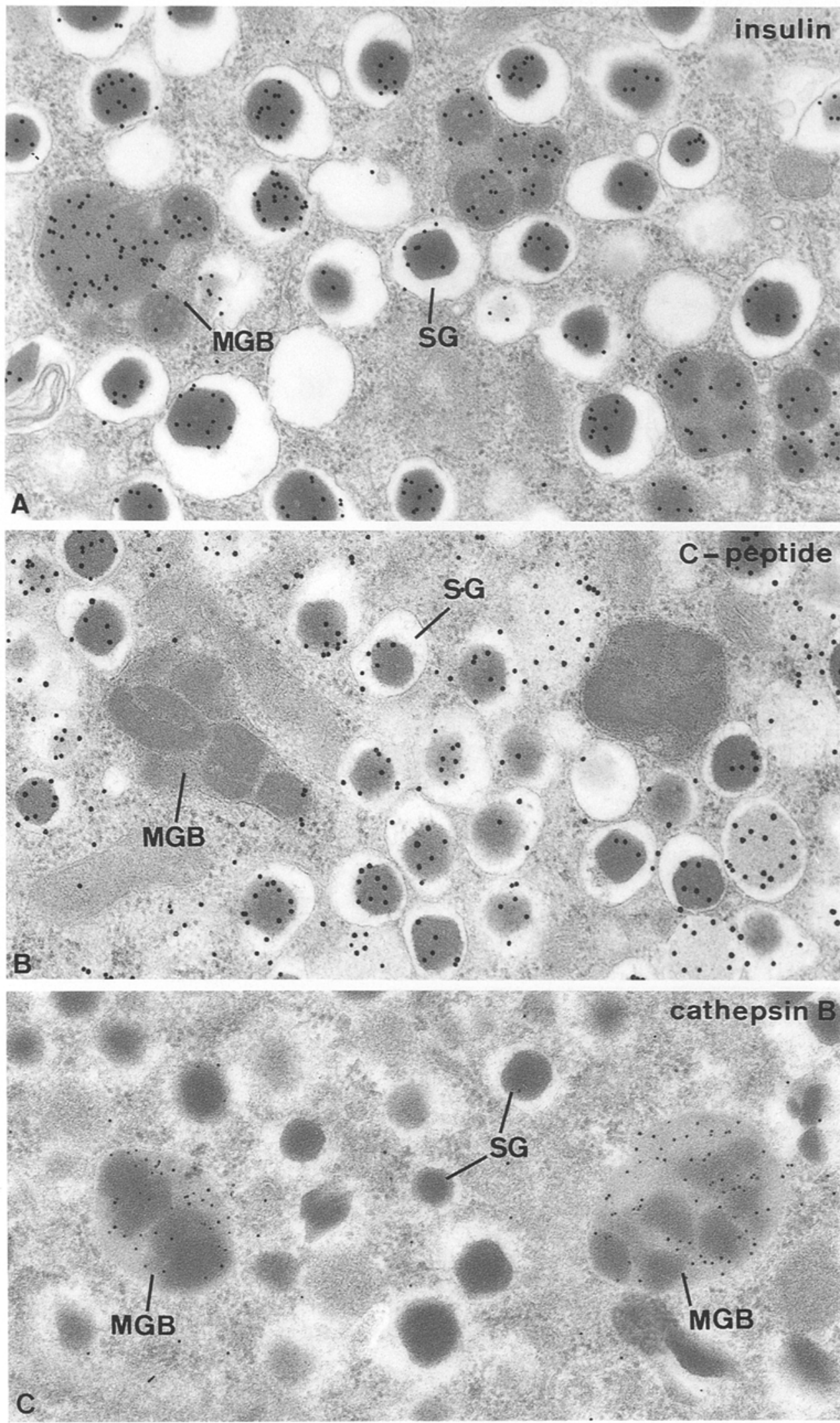

Fig. 11 A-C. Thin sections of B cells immunostained, respectively, with anti-insulin, anti-C-peptide and anti-cathepsin B sera. The fields comprize secretory granules (SG) and multigranular bodies (MGB), and each antiserum reveals a different pattern of protein A-gold labelling. With anti-insulin serum (A) the granule core of secretory granules, as well as the granule core-like material of multigranular bodies is stained. With anti-C-peptide serum (B), only granule cores of secretory granules are labelled. Anticathepsin B serum (C) (provided by Dr. N. Katunuma, Tohushima, Japan) stains the matrix but not the granule core-like material of multigranular bodies, neither the secretory granules. A) and B) 15-nm gold particles; C) 10 -nm gold particles. A $\times 32000 ;$ B $\times 33000 ; \mathbf{C} \times 41000$

C-peptide immunoreactivity. The interesting observation that multigranular bodies contain insulin but no Cpeptide immunoreactivity can be interpreted as follows: in mature secretory granules, insulin may form crystals involving zinc ions and probably excluding C-peptide [36]. Upon fusion of one or several granule(s) with a primary lysosome to form a multigranular body, C-peptide is then likely to be more accessible to and digestible by 

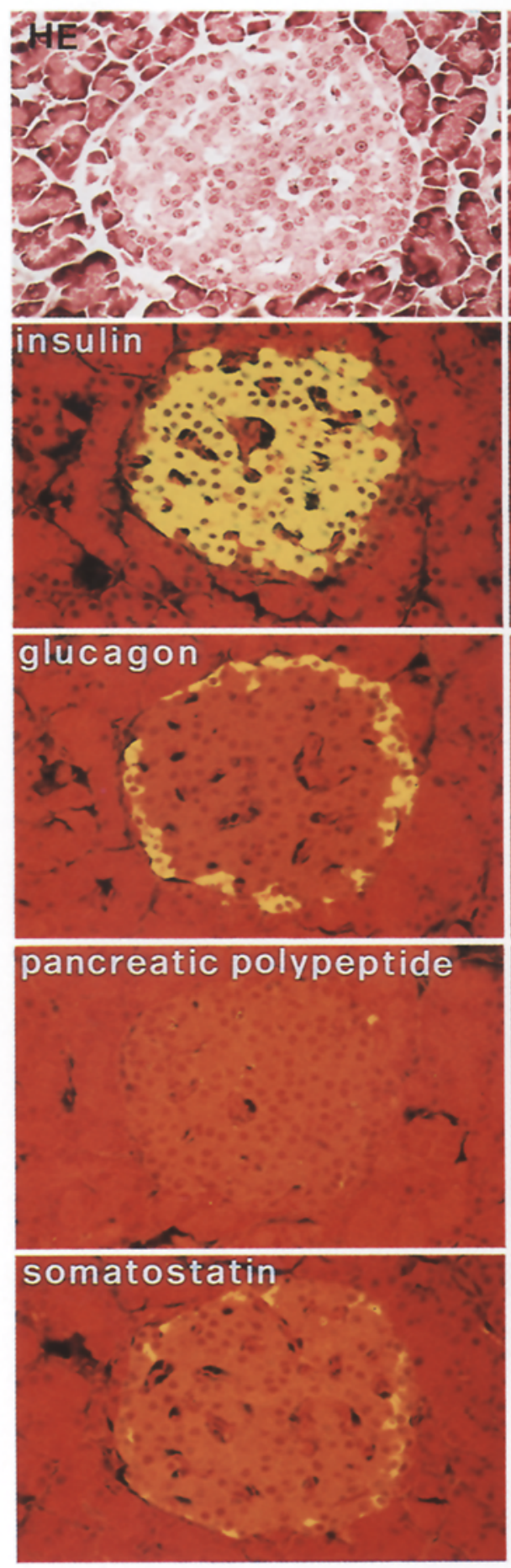
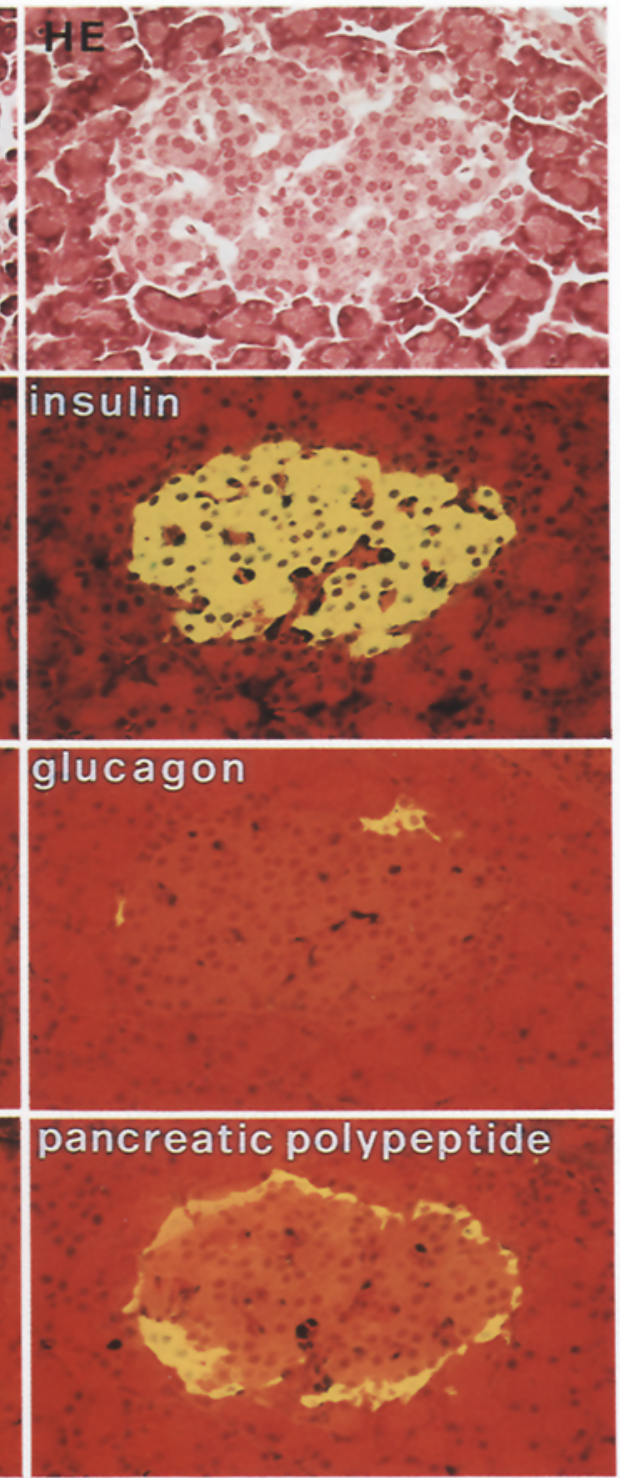

somatostatin

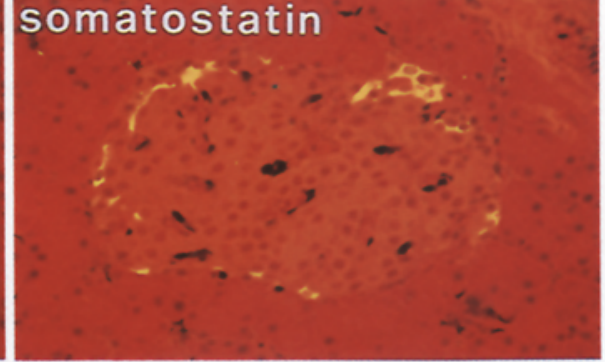

Fig. 12. Successive serial thick sections for light microscopy of two islets of Langerhans stained by immunofluorescence to reveal the distribution of insulin, glucagon, somatostatin and pancreatic polypeptide cells. To the left, an islet from the dorsal region of the pancreas and which is characterized by abundant glucagon cells. To the right, an islet from the ventral pancreatic region and which shows numerous pancreatic polypeptide cells. The hemalum-eosin (HE) sections, by contrast, reveal no difference between the two islet types. Taken from [3]. Left: $\times 190$; Right: $\times 190$ lysosomal enzymes than the compact and relatively insoluble insulin crystals. The data reviewed above thus offer direct evidence that part of the insulin polypeptides are channelled into a lysosomal compartment for degradation.

To conclude this topic, it must be said that for a cell biologist accustomed to visualizing insulin as a secretory polypeptide inserted upon synthesis in the lumen of the RER and assumed not to leave a membrane-limited compartment until it is ultimately discharged by exocy- tosis at the cell surface, it is difficult to deal with several biochemical studies which have identified cytosolic (non-lysosomal) insulin-degrading activity in normal rat islets $[37,38]$. To become accessible to such an enzymatic activity, insulin should cross the granule membrane and reach the cytosol; very sensitive immunocytochemical procedures with anti-insulin antisera have not revealed cytoplasmic antigenic sites above background; however, one could still argue that insulin is degraded as soon as it reaches the cytosol and thus can not be visualized as such. 

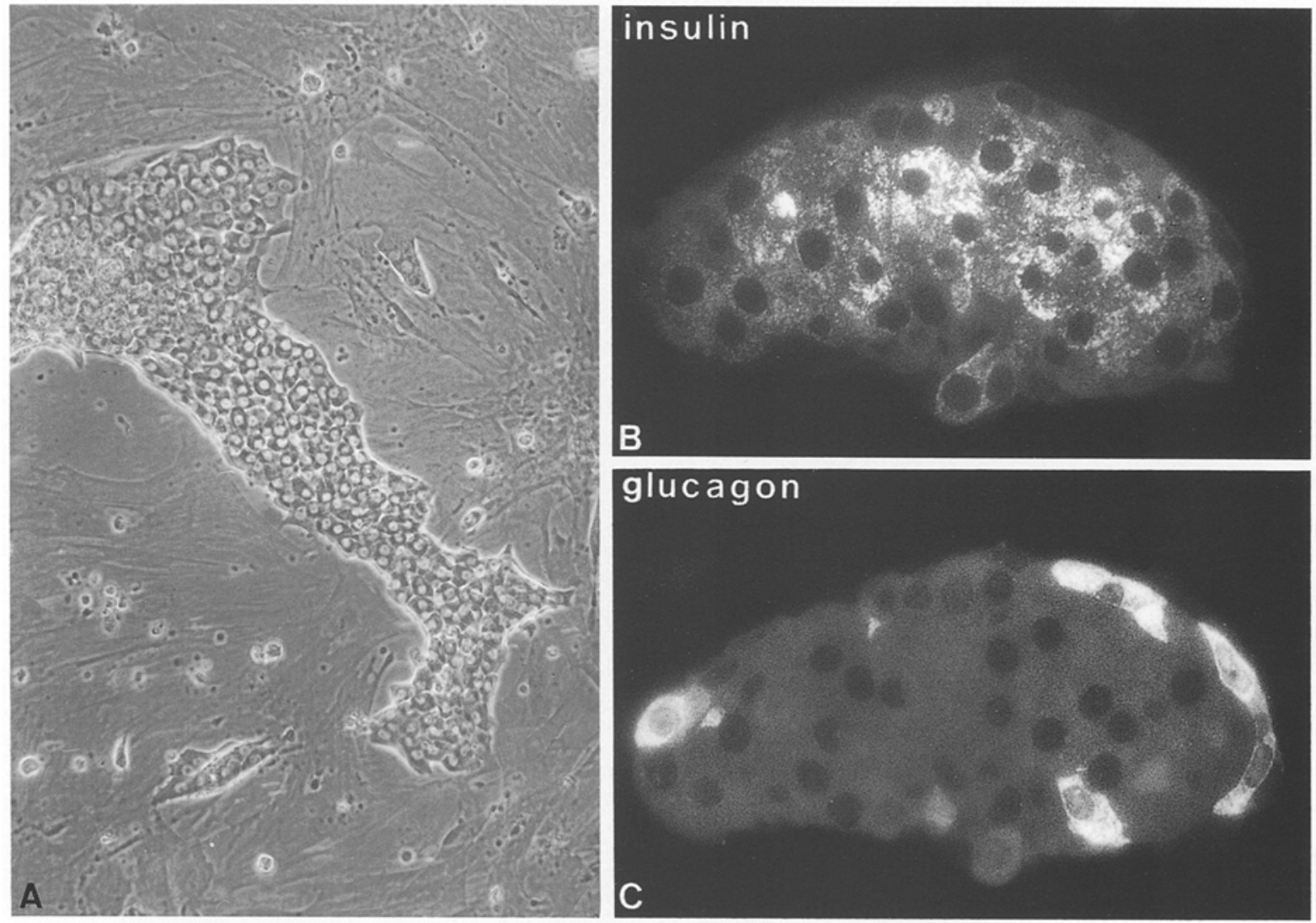

Fig. 13. A Monolayer cluster (with an Italy-like shape) of islet cells grown on a plastic substratum (phase contrast). B, C Successive serial thick sections of an islet-like structure obtained by growing endocrine islet cells in a collagen gel matrix. Immunofluorescent staining with anti-insulin (B) and anti-glucagon (C) sera, respectively, show the central distribution of insulin cells surrounded by peripheral glucagon cells. For detail of the technique see [46]. A $\times 160 ; \mathbf{B}, \mathbf{C} \times 680$

\section{Intercellular contacts within the islet}

During the last 10 years, the notion of "contacts" between islet cells, which was originally used to describe plasma membrane specialisations such as tight and gap junctions and desmosomes (for review, see [39, 40]), was broadened to include intercellular relationships; this has resulted from a systematic analysis of the distribution of insulin-, glucagon-, somatostatin- and pancreatic polypeptide-containing cells in the islet. This revealed, quite unexpectedly, two different types of islets. In one type, a central region of insulin cells was surrounded by a peripheral rim of abundant glucagon cells; the other type showed a similar central region of insulin cells but a peripheral rim made of numerous pancreatic polypeptide-containing cells instead of glucagon cells [41, 42] (Fig. 12). This initial observation was followed by a period of intensive work to establish the general relevance of this finding, and to search for an explanation of the inhomogeneity of islet cell distribution. The glucagon-rich and the pancreatic polypeptide-rich islets have been found in most mammalian species, including man [43]; the duality of islet types appears related to the peculiar mode of formation of the pancreas during embryogenesis: the pancreas originates as two distinct pri- mordia, dorsal and ventral, which merge and fuse during the later stages of development [44]. Glucagon-rich islets are restricted to the area evolved from the dorsal bud, whereas pancreatic polypeptide-rich islets derive from the ventral bud. The latter, in the adult human, forms a separate lobe on the posterior side of the head [43] and an immunofluorescence study of a case of annular pancreas helped us to verify this view [45].

A first clue towards the understanding of how the endocrine cells in the pancreas are organized into such a constant islet pattern has come from the use of in vitro models of the islet. When dissociated pancreatic endocrine cells from neonatal rats are grown on the flat plastic substratum of a Petri dish, they associate into flattened clusters in which the four endocrine cell types are represented, but without any particular distribution reminding that present in the islet in situ (Fig.13 A). Although these monolayer cultures have proven most useful for in vitro studies of endocrine cell function under controlled experimental conditions (e.g. [6]), they have not been suitable for understanding the cell association process(es) presumably operating in vivo. Entirely different results were obtained by an experimental procedure in which dissociated endocrine cells were first grown on a collagen gel, then covered by another layer 

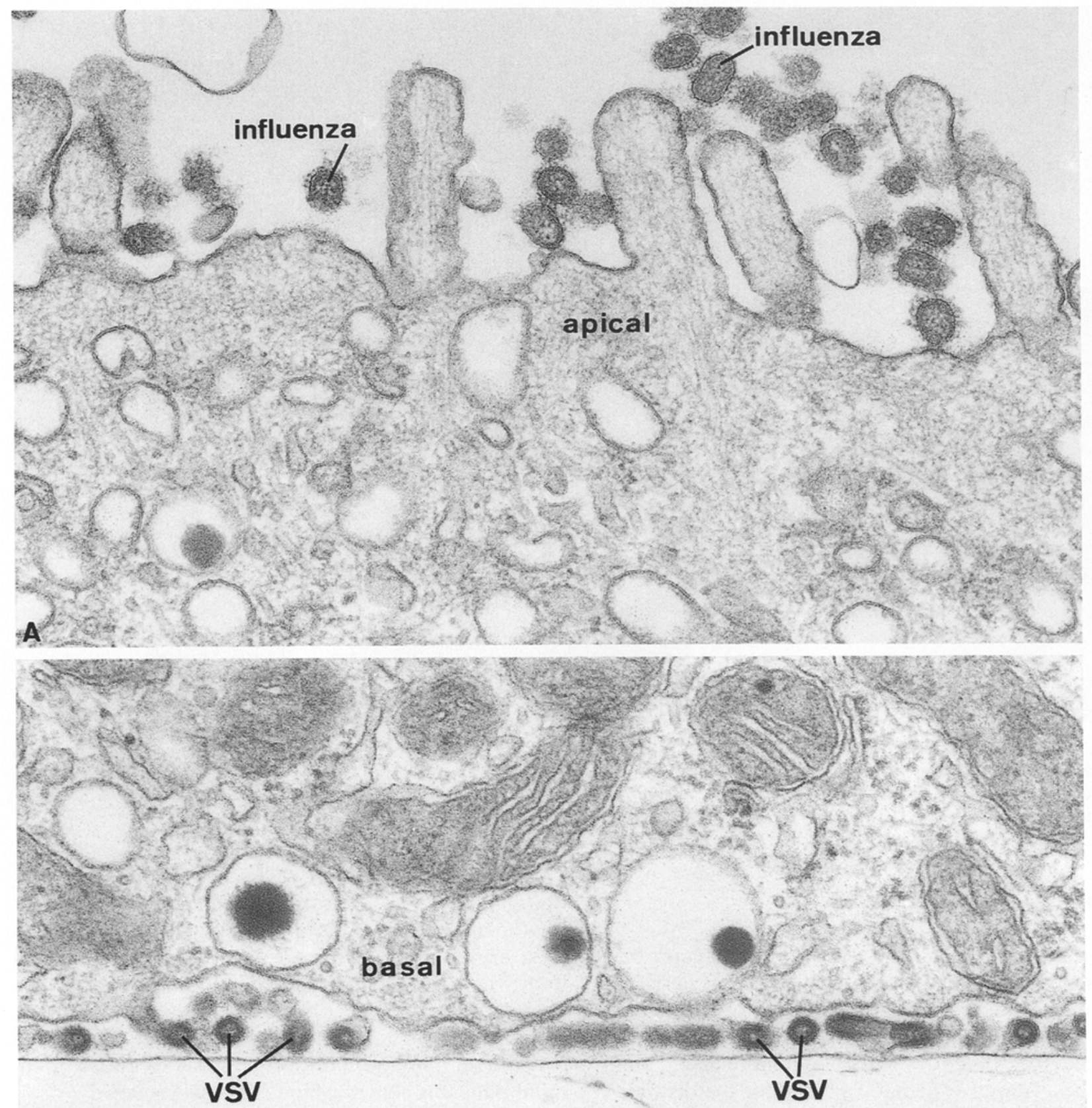

B

Fig. 14 A and B. Thin sections of islet cell monolayer cultures infected with influenza (A) and VSV (B) virus. A Examples of influenza viruses close to the "apical" surface of islet cells (i.e. that bathing free on the culture medium). B "Basal" surface of the monolayer (i.e. attached on the culture substratum appearing as a thin dense line) with numerous VSV viruses in relationship with the basal plasma membrane. Budding of each vinus type from each surface was ascertained by serial thin sectioning. Note that both cells illustrated contain typical $\beta$-secretory granules. For quantitative evaluation of the budding asymmetry, see [50]. $\mathbf{A} \times 84000 ; \mathbf{B} \times 52000$

of collagen. Under such culture conditions, the monolayers of endocrine cells rearranged themselves into smooth contoured, three dimensional aggregates within 3-8 days. In these aggregates, $B$ cells were concentrated in a central position, whereas non $B$ cells (identified by both immunofluorescence and electron microscopy) showed a preferential distribution at the periphery (Fig. 13 B, C) [46].

The specific association of endocrine cells to yield the in vivo islet or the islet-like aggregate in collagen gel cultures implies that islet cells "sense" their surroundings and probably have differently organized membrane domains, or poles, at their periphery. Functional evidence for a "polarity" of islet cells with respect to their exposure to venous or arterial pancreatic blood has been presented [47] but until recently no direct support for polarization was available. In this case again, an in vitro model has helped us to progress. This model is based on the property of certain enveloped RNA viruses to bud selectively from either the apical or basola- 
teral plasma membrane domain in polarized epithelial cells $[48,49]$. We infected monolayers of pancreatic endocrine cells with vesicular stomatitis virus (VSV) and influenza virus and examined the cultures by electron microscopy. Extensive virus budding was observed a few hours after infection (Fig. 14). A quantitative analysis showed that over $90 \%$ of influenza viruses budded from the "apical" domain of the pancreatic endocrine cells, while $88 \%$ of VSV viruses emerged from the "basal" domain. Not only insulin cells, but also glucagon and somatostatin cells in the monolayer showed such polarized budding [50]. In contrast to islet cells, however, fibroblasts present in the culture showed both types of viruses emerging non-selectively from the entire cell periphery. These experiments demonstrate that the influenza virus and VSV emerge asymmetrically from islet cells as they do in polarized epithelia. Previous studies with kidney-derived cells have shown that the polarity of viral budding is a consequence of the asymmetrical insertion of the viral envelope glycoproteins into distinct plasma membrane domains. Thus, our results suggest that cultured pancreatic endocrine cells have the ability to sort out and target different viral proteins to specific plasma membrane domains. In preliminary experiments we have obtained evidence that VSV and influenza viruses also bud from specific membrane domains in intact isolated islets of Langerhans. The available evidence indicates that viral glycoproteins are processed by the cell in the same way as cellular proteins; the sorting ability of islet cells therefore extends to endogenous membrane proteins. If this is the case, the polarized organization of endocrine cells may be an important determinant for their integrated function, and their precise distribution within islets in vivo should then be critical to the physiology of this organ. A search for a polarized distribution of membrane determinants, such as receptors and/or exocytotic sites, is an obvious next step. Since the lipid composition of the viral envelope reflects that of the plasma membrane from which it is derived, by isolating viruses budding from either the apical or basolateral surfaces of pancreatic endocrine cells it should be possible to collect selected samples of these membrane domains and to characterize their lipid composition. The ontogenic mechanism of the organisation of islets is at present mysterious; a search for islet cell-type specific cell adhesion molecules, such as those recently characterized by Edelman [51] in differentiating nervous tissue, may provide insights into this intriguing aspect of organogenesis.

To conclude with a personal note, my wish is that the end of the next 10 years finds me with the same inalterable enthusiasm for the islet of Langerhans as the one I feel today.

\footnotetext{
Acknowledgements. This work was supported by the Swiss National Science Foundation, grant no.3.460.83. I thank Mylène Amherdt, Roberto Montesano, Alain Perrelet, Mariella Ravazzola and JeanDominique Vassalli for their invaluable contribution in the various aspects of this work. I am grateful to Martine Lavanchy, Anne-Marie
}

Lucini, Gorana Perrelet, Gyslaine Tripet and Ariane Widmer for technical assistance, to Gérard Negro and Pierre-Alain Rüttimann for photographic work and to Isabelle Bernard for typing the manuscript.

\section{References}

1. Orci L (1974) A portrait of the pancreatic B-cell. Diabetologia 10: 163-187

2. Orci L (1982) Macro- and micro-domains in the endocrine pancreas. Diabetes 31: 538-565

3. Orci L (1984) Patterns of cellular and subcellular organization in the endocrine pancreas. J Endocrinol 102: 3-11

4. Patzelt C, Labrecque AD, Duguid JR, Carroll RJ, Keim PS, Heinrikson RL, Steiner DF (1978) Detection and kinetic behavior of preproinsulin in pancreatic islets. Proc Natl Acad Sci USA 75: 1260-1264

5. Steiner DF, Kemmler W, Tager HS, Peterson JD (1974) Proteolytic processing in the biosynthesis of insulin and other proteins. Fed Proc 33: 2105-2115

6. Orci L, Like AA, Amherdt M, Blondel B, Kanazawa Y, Marliss EB, Lambert AE, Wollheim CB, Renold AE (1973) Monolayer cell culture of neonatal rat pancreas: An ultrastructural and biochemical study of functioning endocrine cells. J Ultrastr Res 43: 279-297

7. Howell SL, Kostianovski M, Lacy PE (1969) Beta granules formation in isolated islets of Langerhans. A study by electron microscopic radioautography. J Cell Biol 42: 695-705

8. Stäubli W, Schweizer W, Suter J, Weibel ER (1977) The proliferative response of hepatic peroxisomes of neonatal rats to treatment with SU-13437 (nafenopin). J Cell Biol 74: 665 689

9. Whur P, Herskovics A, Leblond CP (1969) Radioautographic visualization of the incorporation of galactose- ${ }^{3} \mathrm{H}$ and mannose $-{ }^{3} \mathrm{H}$ by rat thyroids in vitro in relation to the stages of thyroglobulin synthesis. J Cell Biol 43: 289-311

10. Tartakoff AM (1983) Perturbation of vesicular traffic with the carboxylic ionophore monensin. Cell 32: 1026-1028

11. Noe BD (1981) Inhibition of islet prohormone to hormone conversion by incorporation of arginine and lysine analogs. J Biol Chem 256: $4940-4946$

12. Orci L, Halban P, Amherdt M, Ravazzola M, Vassalli JD, Perrelet A (1984) A clathrin-coated, Golgi-related compartment of the insulin secreting cell accumulates proinsulin in the presence of monensin. Cell 39: 39-47

13. Orci L, Halban P, Amherdt M, Ravazzola M, Vassalli JD, Perrelet A (1984) Nonconverted, amino acid analog-modified proinsulin stays in a Golgi-derived clathrin-coated membrane compartment. J Cell Biol 99: 2187-2192

14. Madsen OD, Frank BH, Steiner DF (1984) Human proinsulin-specific antigenic determinants identified by monoclonal antibodies. Diabetes 33: 1012-1016

15. Sly WS, Fischer HD (1982) The phosphomannosyl recognition system for intracellular and intercellular transport of lysosomal enzymes. J Cell Biochem 18: 67-85

16. Brown WJ, Farquhar MG (1984) The mannose-6-phosphate receptor for lysosomal enzymes is concentrated in cis Golgi cisternae. Cell 36: 295-307

17. Geuze HJ, Slot JW, Strous GJAM, Hasilik A, Von Figura K (1984) Ultrastructural localization of the mannose 6-phosphate receptor in rat liver. J Cell Biol 98: 2047-2054

18. Orci L, Ravazzola M, Perrelet A (1984) (Pro)insulin associates with Golgi membranes of pancreatic B-cells. Proc Natl Acad Sci USA 81: 6743-6746

19. Goldstein JL, Anderson RGW, Brown MS (1979) Coated pits, coated vesicles, and receptor-mediated endocytosis. Nature 279: 679-685

20. Pearse BMF, Bretscher MS (1981) Membrane recycling by coated vesicles. Ann Rev Biochem 50: 85-101

21. Louvard D, Morris C, Warren G, Stanley K, Winkler F, Reggio H 
(1983) A monoclonal antibody to the heavy chain of clathrin. EMBO J 2: 1655-1664

22. Orci L, Ravazzola M, Amberdt M, Louvard D, Perrelet A (1985) Clathrin immunoreactive sites in the Golgi apparatus are concentrated at the trans pole in polypeptide hormone secreting cells. Proc Natl Acad Sci USA, August 1985

23. Stone DK, Xie XS, Racker E (1983) An ATP-driven proton pump in clathrin-coated vesicles. J Biol Chem 258: 4059-4062

24. Forgac M, Cantley L, Wiedenmann B, Altstiel L, Branton D (1983) Clathrin-coated vesicles contain an ATP-dependent proton pump. Proc Natl Acad Sci USA 80: 1300-1303

25. Glickman J, Croen K, Kelly S, Al-Awqati Q (1983) Golgi membranes contain an electrogenic $\mathrm{H}^{+}$pump in parallel to a chloride conductance. J Cell Biol 97: 1303-1308

26. Docherty K, Carroll RJ, Steiner DF (1982) Conversion of proinstlin to insulin: Involvement of a 31500 molecular weight thiol protease. Proc Natl Acad Sci USA 79: 4613-4617

27. Hutton JC (1982) The internal $\mathrm{pH}$ and membrane potential of the insulin-secretory granules. Biochem J 204: 171-178

28. Anderson RGW, Falck JR, Goldstein JL, Brown MS (1984) Visualization of acidic organelles in intact cells by electron microscopy. Proc Natl Acad Sci USA 81: 4838-4842

29. Anderson RGW, Pathak RK (1985) Vesicles and cisternae in the trans Golgi apparatus of human fibroblasts are acidic compartments. Cell 40:635-643

30. Brown D, Orci L (1983) Vasopressin stimulates formation of coated pits in rat kidney collecting ducts. Nature 302: 253-255

31. Halban PA, Wollheim CB (1980) Intracellular degradation of insulin stores by pancreatic islets in vitro: An alternative pathway for homeostasis of pancreatic insulin content. J Biol Chem 255: 6003-6006

32. Halban PA, Wollheim CB, Blondel B, Renold AE (1980) Long term exposure of isolated pancreatic islets to mannoheptulose. Evidence for insulin degradation in the B-cell. Biochem Pharmacol 29:2625-2633

33. Smith RE, Farquhar MG (1966) Lysosome function in the regulation of the secretory process in cells of the anterior pituitary gland. J Cell Biol 31: 319-346

34. Orci L, Junod A, Pictet R, Renold AE, Rouiller Ch (1968) Granulolysis in A cells of endocrine pancreas in spontaneous and experimental diabetes in animals. J Cell Biol 38: 462-466

35. Orci L, Ravazzola M, Amherdt M, Yanaihara C, Yanaihara N, Halban P, Renold AE, Perrelet A (1984) Insulin, not C-peptide (proinsulin), is present in crinophagic bodies of the pancreatic $B$ cell. J Cell Biol 98: 222-228

36. Emdin SO, Dodson GG, Cutfield JM, Cutfield SM (1980) Role of zinc in insulin biosynthesis. Diabetologia 19: 174-182

37. Kohnert KD, Jahr H, Schmidt S, Hahn HJ, Zuhlke H (1976) Demonstration of insulin degradation by thio-protein disulfide oxidoreductase (glutathione-insulin-transhydrogenase) and proteinases of pancreatic islets. Biochim Biophys Acta 422: 254-259

38. Bhathena SJ, Timmers KI, Oie HK, Voyles NR, Recant L (1985) Cytosolic insulin-degrading activity in islet-derived tumor cell lines and in normal rat islets. Diabetes 34: 121-128

39. Orci L, Perrelet A (1977) Morphology of membrane systems in pancreatic islets. In: Volk BW, Wellmann KF (eds). The diabetic pancreas, Ch. 7. Plenum, New York, pp 171-210

40. Meda P, Perrelet A, Orci L (1984) Gap junctions and cell-to-cell coupling in endocrine glands. In: Satir BH (ed). Modern cell biology, Vol. 3. Alan Liss, New York, pp 131-196

41. Orci L, Baetens D, Ravazzola M, Stefan Y, Malaisse-Lagae F (1976) Pancreatic polypeptide and glucagon: non-random distribution in pancreatic islets. Life Sci 19: 1811-1815

42. Baetens D, Malaisse-Lagae F, Perrelet A, Orci L (1979) Endocrine pancreas: Three-dimensional reconstruction shows two types of islets of Langerhans. Science 206: 1323-1325

43. Malaisse-Lagae F, Stefan Y, Cox J, Perrelet A, Orci L (1979) identification of a lobe in the adult human pancreas rich in pancreatic polypeptide. Diabetologia 17:361-365

44. O'Rahilly R, Müller F (1978) A model of the pancreas to illustrate its development. Acta Anat (Basel) 100: 380-385

45. Stefan Y, Grasso S, Perrelet A, Orci L (1982) The pancreatic polypeptide-rich lobe of the human pancreas: definitive identification of its derivation from the ventral pancreatic primordium. Diabetologia 23: 141-142

46. Montesano R, Mouron P, Amherdt M, Orci L (1983) Collagen matrix promotes reorganization of pancreatic endocrine cell monolayers into islet-like organoids. J Cell Biol 97: 935-939

47. Kawai K, Orci L, Perrelet A, Ipp E, Unger RH (1982) Circulating somatostatin acts on the islets of Langerhans via a somatostatinpoor compartment. Science 218: 477-478

48. Rodriguez-Boulan E, Sabatini DD (1978) Asymmetric budding of viruses in epithelial monolayers: a model system for study of epithelial polarity. Proc Natl Acad Sci USA 75: 5071-5075

49. Rodriguez-Boulan E, Pendergast M (1980) Polarized distribution of viral envelope proteins in the plasma membrane of infected epithelial cells. Cell 20:45-54

50. Lombardi T, Montesano R, Wohlwend AL, Amherdt M, Vassal* li JD, Orci L (1985) Evidence for polarization of plasma membrane domains in pancreatic endocrine cells. Nature 313:694-696

51. Edelman GM (1984) Cell adhesion molecules. Science 219: 450-457

52. Orci L, Carpentier JL, Perrelet A, Anderson RGW, Goldstein JL, Brown MS (1978) Occurrence of low density lipoprotein receptors within large pits on the surface of human fibroblasts as demonstrated by freeze-etching. Exp Cell Res 113: 1-13

53. Montesano R, Perrelet A, Vassalli P, Orci L (1979) Absence of filipin-sterol complexes from large coated pits on the surface of culture cells. Proc Natl Acad Sci USA 76: 6391-6395

54. Roth J, Bendayan M, Orci L (1978) Ultrastructural localization of intracellular antigens by the use of protein A-gold complex. J Histochem Cytochem 26: 1074-1081

55. Armbruster BL, Carlemalm E, Chiovetti R, Garavito RM, Hobot JA, Kellenberger E, Villiger W (1982) Specimen preparation for electron microscopy using low temperature embedding resins. J Microse 126: 77-85

56. Madsen OD, Cohen RM, Fitch FW, Rubenstein AH, Steiner DF (1983) The production and characterization of monoclonal antibodies specific for human proinsulin using a sensitive microdot assay procedure. Endocrinology 113: 2135-2144

Professor L. Orci

Institute of Histology and Embryology

University of Geneva Medical School

$\mathrm{CH}-1211$ Geneva 4

Switzerland 